\title{
On the effect of chelating agents and antioxidants on cadmium-induced organ toxicity. An overview
}

\author{
Juliana Ivanova a,*, Yordanka Gluhcheva b, Denitsa Tsanova a, Angelina Piskova a, Radostina Djaleva a, \\ Steliana Mokresheva a, Dimitrina Kamenova a, and Mariana Mitewa c
}

a Faculty of Medicine, Sofia University "St. Kl. Ohridski", 1407 Sofia, Bulgaria

b Institute of Experimental Morphology, Pathology and Anthropology with Museum, BAS, 1113, Sofia, Bulgaria

c Faculty of Chemistry and Pharmacy, Sofia University, "St. Kl. Ohridski", 1164 Sofia, Bulgaria

${ }^{*}$ Corresponding author at: Faculty of Medicine, Sofia University "St. Kl. Ohridski", 1407 Sofia, Bulgaria

Tel.: +359.2.8161247; fax: +359.2.9625438. E-mail address: dkji@chem.uni-sofia.bg (J. Ivanova).

\section{REVIEW INFORMATION}

Received: 31 January 2013

Accepted: 16 February 2013

Online: 31 March 2013

\section{KEYWORDS}

\section{Vitamins}

Cadmium

Toxicology

Ionophores

Antioxidants

Medicinal chemistry

\section{ABSTRACT}

Cadmium (Cd) has been classified as a human carcinogen. The World Health Organization (WHO) reported that the concentration of $\mathrm{Cd}$ in the environment has rapidly increased in the last few years. In many epidemiological studies, the correlation between environmental exposure of humans to $\mathrm{Cd}$ and diseases such as stroke, ischemia, renal and hepatic dysfunction, anemia, osteoporosis and diabetes has been discussed. For the treatment of heavy metal intoxications a therapy with chelating agents has been applied. A chelating agent is a compound that binds the toxic metal ion thus promoting its excretion by the living organisms. Recently, it has been found that Cd-induced toxicity is a result of formation of reactive oxygen species (ROS). These results increased the interest towards the antioxidants as possible agents for the treatment of Cd-induced organ toxicity. Herein, we present summary and discussion of the literature data for the influence of chelating agents and antioxidants on Cd-induced pathological conditions in Cd-intoxicated animals.

\section{Introduction}

Cadmium (Cd) is a toxicant, classified as a human carcinogen by the International Agency for Research on Cancer [1]. According to the data provided by the WHO, the daily $\mathrm{Cd}$ intake varies in the interval from $40 \mu \mathrm{g}$ (for people living in unpolluted regions) to $200 \mu \mathrm{g}$ (for people from polluted areas) $[2,3]$. The level at which chronic exposure to $\mathrm{Cd}$ is not likely to cause cancer or adverse health effects is $14 \mu \mathrm{g}$ per day [2,3]. $\mathrm{Cd}$ is a very dangerous environmental pollutant due to its ability to cause severe organ toxicity. When accumulated in the body it induces hepatotoxicity [4], renal dysfunction [5,6], distortion of the reproductive function $[7,8]$ and cardiovascular injury [914].

Compounds that possess low toxicity, good absorbability by the gastrointestinal tract and bind toxic metal ions have been used in the chelation therapy for the treatment of toxic metal intoxication [15-17]. Many chelating agents have been tested to mobilize Cd but no effective chelation therapy is available so far for humans, exposed to Cd intoxication [18].

It has been discussed that the oxidative stress is one of the mechanisms for the Cd-induced toxicity [19-21]. Albeit Cd does not generate free radicals by itself it replaces the iron (Fe) and copper $(\mathrm{Cu})$ from cytoplasmic proteins and metalloenzymes [19]. Free iron and copper ions participate in Fenton type reactions leading to the generation of ROS [19-21]. Other possible mechanism for $\mathrm{Cd}$-induced oxidative stress includes direct interaction of Cd with SH groups of the thiols $[20,21]$. In the last years enormous data regarding the application of the antioxidants for the treatment of Cd-induced toxicity have been published [3].
Herein we present a summary of the antioxidants and chelating agents screened on animal models to decrease Cd concentrations in the body and to prevent $\mathrm{Cd}$-induced oxidative stress. The data presented in this review comprise the period 1992-2012 years. Discussion of the antioxidants and chelating agent tested to inhibit Cd-induced hepatotoxicity, renal dysfunction, testicular toxicity and cardiac impairment is provided.

\section{Effect of antioxidants and chelating agents on Cd- induced hepatotoxicity}

The liver and kidneys are critical organs in Cd-induced intoxications. When accumulated in the liver $\mathrm{Cd}$ induces inflammatory cell infiltrations, dilation of sinosoids and disorganization of the normal radiating pattern of the hepatocytes around the central vein [22-24]. At acute and longlasting chronic $\mathrm{Cd}$-intoxications necrosis of the central vein of the liver has been observed [22].

\subsection{Antioxidants, tested on animal models for the treatment of Cd-induced hepatotoxicity}

The antioxidants tested on animal models to prevent $\mathrm{Cd}$ induced hepatotoxicity are presented in Tables 1 and 2. As could be seen from the data, presented in both tables, there is an enormous diversity of experimental models, published by authors of studies dealing with the effect of the antioxidants on Cd-induced hepatotoxicity. 
Table 1. Antioxidants, tested on animal models for the treatment of Cd-induced hepatotoxicity, caused by acute and subacute Cd-exposure.

\begin{tabular}{|c|c|c|c|c|c|}
\hline Antioxidant & $\begin{array}{l}\text { Route of } \\
\text { administration }\end{array}$ & $\begin{array}{l}\text { Dose and duration of } \\
\text { administration }\end{array}$ & Animal model & Effect & Ref. \\
\hline $\begin{array}{l}\text { Alpha lipoic acid } \\
(\alpha-L A)\end{array}$ & i.p. & $\begin{array}{l}\text { LA:Cd = 5:1. The } \\
\text { antioxidant is co- } \\
\text { administrated with Cd(II) } \\
\text { salt }\end{array}$ & $\begin{array}{l}\text { Male mice, acute intoxicated } \\
\text { with } 40 \mu \mathrm{mol} / \mathrm{kg} \text { Cd(II) salt } \\
\text { (s.c.) }\end{array}$ & $\begin{array}{l}\text { Cd accumulation is not affected by LA. The } \\
\text { antioxidant does not recover the activity of CAT } \\
\text { and GSH level, but the mortality associated with } \\
\text { Cd-intoxication is decreased by LA. }\end{array}$ & [25] \\
\hline Curcumin & p.o. & $\begin{array}{l}50 \mathrm{mg} / \mathrm{kg} \text { b.w., applied } \\
\text { before Cd-intoxication for } \\
3 \text { days }\end{array}$ & $\begin{array}{l}\text { Male mice and male rats, } \\
\text { acute intoxicated with } 0,025 \\
\text { and } 0,03 \mathrm{mmol} / \mathrm{kg} \text { b.w. } \\
\text { Cd(II) chloride (s.c.) }\end{array}$ & $\begin{array}{l}\text { LPO is abolished by the antioxidant, but Cd- } \\
\text { induced GSH depletion in the mice liver is not } \\
\text { significantly affected. Cd concentration and trace } \\
\text { elements homeostasis are not changed by the } \\
\text { antioxidant. }\end{array}$ & [26] \\
\hline $\begin{array}{l}\text { Curcumin and } \mathrm{Mn-} \\
\text { curcumin complex }\end{array}$ & p.o. & $\begin{array}{l}0,14 \mathrm{mmol} / \mathrm{kg} \text { b.w, } \\
\text { applied for } 3 \text { days before } \\
\text { intoxication }\end{array}$ & $\begin{array}{l}\text { Male mice, intoxicated s.c. } \\
\text { with } 33 \mu \mathrm{mol} / \mathrm{kg} \mathrm{Cd}(\mathrm{II}) \\
\text { chloride }\end{array}$ & $\begin{array}{l}\text { Both compounds prevent Cd-induced decrease of } \\
\text { GSH but do not affect Cd accumulation. The } \\
\text { treatment with Mn complexes causes an increase } \\
\text { of Fe and } \mathrm{Mn} \text { in the kidneys in the control and Cd- } \\
\text { treated mice and Fe and Cu in the brain of the } \\
\text { control mice. }\end{array}$ & [27] \\
\hline $\begin{array}{l}\text { Curcumin, } \\
\text { resveratol, } \\
\text { melatonin }\end{array}$ & p.o. & $\begin{array}{l}50 \mathrm{mg} / \mathrm{kg} \text { b.w. curcumin; } \\
20 \mathrm{mg} / \mathrm{kg} \text { b.w - } \\
\text { resveratrol; melatonin - } \\
12 \mathrm{mg} / \mathrm{kg} \text {, dispersed in } \\
0.5 \% \text { methylcellulose. } \\
\text { Duration - } 3 \text { days }\end{array}$ & $\begin{array}{l}\text { Male mice, intoxicated with } \\
\text { Cd(II) chloride }(7 \mathrm{mg} / \mathrm{kg} \\
\text { b.w., s.c.) }\end{array}$ & $\begin{array}{l}\text { The Cd-induced decrease of GSH level in the liver } \\
\text { is not prevented by the antioxidants. Resveratol } \\
\text { recovers CAT activity.The MDA and GPx level is } \\
\text { returned to normal in the pretreated animals. The } \\
\text { antioxidants do not affect Cd accumulation. }\end{array}$ & [28] \\
\hline Vitamin E & $\begin{array}{l}\text { Information not } \\
\text { found }\end{array}$ & $\begin{array}{l}100 \mathrm{mg} / \mathrm{kg} \text {, applied before } \\
\text { intoxication }\end{array}$ & $\begin{array}{l}\text { Male rats, intoxicated i.v. } \\
\text { with } 2 \mathrm{mg} / \mathrm{kg} \text { Cd (II) }\end{array}$ & $\begin{array}{l}\text { Vit. E improves SOD and CAT activity in the liver } \\
\text { as well as GSH level. The antioxidant has been } \\
\text { shown to recover Hb and HCT in the blood. }\end{array}$ & [32] \\
\hline $\begin{array}{l}\text { Diallyl tetrasulfide } \\
\text { (DTS) }\end{array}$ & p.o. & $\begin{array}{l}40 \mathrm{mg} / \mathrm{kg} \text { (optimum dose) } \\
\text { for } 3 \text { weeks, applied } \\
\text { together with Cd(II) }\end{array}$ & $\begin{array}{l}\text { Male rats, intoxicated with } 3 \\
\mathrm{mg} / \mathrm{kg} \text { Cd(II) s.c. for } 3 \text { weeks }\end{array}$ & $\begin{array}{l}\text { DTS significantly reduces the accumulation of Cd } \\
\text { and restores the levels of the antioxidant defense } \\
\text { in the liver. DTS improves the hepatocytes } \\
\text { morphology. }\end{array}$ & {$[29,30]$} \\
\hline $\begin{array}{l}\text { Endomorophin } 1 \\
\text { (EM1) }\end{array}$ & i.p. & $\begin{array}{l}50 \mu \mathrm{M} / \mathrm{kg} \text { per day for } 6 \\
\text { days - optimum dose. The } \\
\text { antioxidant has been } \\
\text { coadministrated with Cd } \\
\text { (II) }\end{array}$ & $\begin{array}{l}\text { Male mice, injected i.p. with } \\
\text { Cd(II) chloride }(1 \mathrm{mg} / \mathrm{kg} \text { per } \\
\text { day) for } 6 \text { days }\end{array}$ & $\begin{array}{l}\text { EM1 reduces the Cd accumulation up to } 28 \% \\
\text { compared to the toxic control. EM1 attenuates Cd- } \\
\text { induced alterations in MDA levels, GSH, SOD, and } \\
\text { CAT but MDA values remain higher than the } \\
\text { controls. On the morphological level, the } \\
\text { degenerative changes are reduced by EM1. }\end{array}$ & [31] \\
\hline Taurine & p.o. & $\begin{array}{l}150 \mathrm{mg} / \mathrm{kg} \text { body weight, } \\
\text { once daily for } 5 \text { days prior } \\
\text { Cd-intoxication }\end{array}$ & $\begin{array}{l}\text { Mice received Cd (II) } \\
\text { chloride orally through } \\
\text { drinking water at a dose of } 4 \\
\mathrm{mg} / \mathrm{kg} \text { b.w. for } 6 \text { days, once } \\
\text { daily }\end{array}$ & $\begin{array}{l}\text { Taurine significantly increases SOD and CAT } \\
\text { activity but at optimum dose the values remains } \\
15 \% \text { and } 20 \% \text { lower than the controls. Taurine } \\
\text { prevents Cd accumulation by } 50 \% \text { and preserves } \\
\text { the homeostasis of the trace elements. } \\
\text { Considerable improvement of the liver } \\
\text { morphology by the antioxidant is observed. }\end{array}$ & [22] \\
\hline Panax ginseng (Pg) & p.o. & $\begin{array}{l}10 \mathrm{mg} / \mathrm{kg} \\
\text { b. w. for } 10 \text { days prior to } \\
\text { Cd-intoxication and } \\
\text { continued up to } 30 \text { days } \\
\text { after Cd(II) chloride } \\
\text { administration }\end{array}$ & $\begin{array}{l}\text { Male mice, acute intoxicated } \\
\text { with Cd(II) chloride (1 } \\
\mathrm{mg} / \mathrm{kg} \text { b. w., i.p. once) }\end{array}$ & $\begin{array}{l}\text { The antioxidant recovers GSH and ALP. TBARS is } \\
\text { partly affected by Pg. TBARS levels remain higher } \\
\text { than the control (about } 20 \% \text { ). }\end{array}$ & {$[34]$} \\
\hline Carnosine & i.p. & $\begin{array}{l}10 \mathrm{mg} / \mathrm{kg} / \text { day is applied } \\
\text { for three consecutive } \\
\text { days, starting one day } \\
\text { before Cd- } \\
\text { administration }\end{array}$ & $\begin{array}{l}\text { Male mice, acute intoxicated } \\
\text { with } 6.5 \mathrm{mg} / \mathrm{kg} \mathrm{Cd}(\mathrm{II}) \\
\text { chloride i.p. }\end{array}$ & $\begin{array}{l}\text { The antioxidant partly reduces MDA, and } \\
\text { increases GSH, CAT and SOD. CAT, SOD and GSH } \\
\text { remain lower with } 15 \%, 20 \% \text {, and } 10 \% \\
\text { respectively than the controls. Carnosine } \\
\text { decreased by } 87 \% \text { Cd concentration and } \\
\text { recovered Zn homeostasis. On the morphological } \\
\text { level a significant improvement of the radiating } \\
\text { hepatocytes structure is observed in carnosine } \\
\text { treated mice. }\end{array}$ & [23] \\
\hline $\begin{array}{l}\text { Solublequercetin- } \\
50 \text {-sulfonic acid } \\
\text { sodiumsalt } \\
\text { (NaQSA); } \\
\text { andmorin-50- } \\
\text { sulfonic acid } \\
\text { sodium salt } \\
\text { (NaMSA) }\end{array}$ & i.p. & $\begin{array}{l}20 \mathrm{mg} / \mathrm{kg} \text { b.w. after Cd- } \\
\text { intoxication } \\
10 \mathrm{mg} / \mathrm{kg} \text { in combination } \\
\text { of both flavanoids }\end{array}$ & $\begin{array}{l}\text { Male mice, intoxicated with } \\
0.64 \mathrm{mg} / \mathrm{kg} \text { b.w } \mathrm{Cd}(\mathrm{II}) \\
\text { chloride s.c. }\end{array}$ & $\begin{array}{l}\text { Both antioxidants increased the level of SOD and } \\
\text { GSH, but the values remained lower than the } \\
\text { controls ( } 30 \% \text { and } 20 \% \text { respectively). }\end{array}$ & [35] \\
\hline $\begin{array}{l}\text { Garlic and Ascorbic } \\
\text { acid }\end{array}$ & p.o. & $\begin{array}{l}100 \mathrm{mg} / \mathrm{kg} \text {, pretreated for } \\
4 \text { weeks }\end{array}$ & $\begin{array}{l}\text { Male rats - acute intoxicated } \\
\text { with Cd (II) chloride } 4 \\
\mathrm{mg} / \mathrm{kg} \text { b.w. } \\
\text { (i.p.). }\end{array}$ & $\begin{array}{l}\text { The antioxidants recover SOD and CAT activity } \\
\text { and return to normal the LPO level. }\end{array}$ & [33] \\
\hline
\end{tabular}

In most papers, however, the effect of the antioxidants on Cd-induced oxidative stress in the liver is monitored by the analysis of superoxide dismutase activity (SOD), catalase activity (CAT), gluthathione level (GSH) and level of lipid peroxidation (LPO), expressed as thiobarbituric acid reactive species (TBRAS) or malondyaldehyde (MDA). Cd decreases the level of GSH, and the activity of SOD and CAT in the liver of Cdintoxicated animals and induces a significant increase of LPO. All antioxidants studied have been demonstrated to prevent in some extent Cd-induced oxidative stress in the liver of Cdtreated animals.

\subsubsection{Effect of antioxidants on Cd-induced hepatoxicity in animals, subjected to acute and subacute Cd-intoxications}

The antioxidants, screened on animal models for the treatment of Cd-induced hepatotoxicity, caused by acute and subacute Cd-exposure, are presented on Table 1. 
Table 2. Antioxidants, tested on animal models for the treatment of Cd-induced hepatotoxicity in subchronic and chronic Cd-intoxications.

\begin{tabular}{|c|c|c|c|c|c|}
\hline Antioxidant & $\begin{array}{l}\text { Route of } \\
\text { administration }\end{array}$ & Dose & Animal model & Effect & Ref. \\
\hline $\begin{array}{l}\text { Hydroxytyrosol, } \\
\text { (DPE) }\end{array}$ & $\begin{array}{l}\text { Information not } \\
\text { found }\end{array}$ & $\begin{array}{l}9 \mathrm{mg} / \mathrm{kg} \text {, applied after } \\
\text { Cd-intoxication }\end{array}$ & Male rats & DPE inhibits Cd-induced toxicity in the liver & [42] \\
\hline $\begin{array}{l}\text { Diphenyl diselenide } \\
\left((\mathrm{PhSe})_{2}\right)\end{array}$ & s.c. & $5 \mu \mathrm{mol} / \mathrm{kg}$ & $\begin{array}{l}\text { Male mice, subchronically } \\
\text { intoxicated with } 10 \mu \mathrm{mol} \\
\text { Cd(II) salt five times per } \\
\text { week for four weeks }\end{array}$ & $\begin{array}{l}\text { The antioxidant restores the activity of AST and TBARS } \\
\text { to normal values. Diphenyl diselenide decreases ALT } \\
\text { activity in the plasma of Cd-treated mice but the value } \\
\text { remains higher than the controls ( } 70 \%) \text {. The effect of } \\
\text { the antioxidant on the Cd and trace elements level is } \\
\text { not studied. }\end{array}$ & [36] \\
\hline Melatonin & p.o & $\begin{array}{l}4 \mu \mathrm{g} / \mathrm{mL} \text { for } 8 \text { weeks } \\
\text { applied together with } \\
\text { Cd(II) }\end{array}$ & $\begin{array}{l}\text { Female and male mice, } \\
\text { subchronically intoxicated } \\
\text { with } 50 \mu \mathrm{g} \mathrm{Cd} / \mathrm{mL} \text { as } \mathrm{Cd}(\mathrm{II}) \\
\text { chloride for } 8 \text { weeks }\end{array}$ & $\begin{array}{l}\text { Melatonin decreases Cd level by } 24 \% \text { compared to the } \\
\text { toxic control; the antioxidant however decreases } \\
\text { hepatic iron to } 14 \% \text { compared to the toxic control. Cd } \\
\text { diminishes Fe level to } 20 \% \text { compared to the control; } \\
\text { TBRAS levels are recovered by the antioxidant and are } \\
\text { even lower than the normal control. }\end{array}$ & [38] \\
\hline $\begin{array}{l}\text { Hibiscus sabdariffa } \\
\text { L petal }\end{array}$ & $\begin{array}{l}\text { Information not } \\
\text { found }\end{array}$ & $\begin{array}{l}\text { Applied before } \\
\text { intoxication }\end{array}$ & $\begin{array}{l}\text { Male rats, chronically } \\
\text { intoxicated with Cd(II) }\end{array}$ & $\begin{array}{l}\text { The antioxidant decreases the levels of AST and ALT in } \\
\text { the blood plasma. }\end{array}$ & [43] \\
\hline $\begin{array}{l}\text { Diphenyl diselenide, } \\
(\mathrm{PhSe})_{2}\end{array}$ & p.o. & $\begin{array}{l}5 \mu \mathrm{mol} / \mathrm{kg} \text {, applied } \\
\text { together with Cd(II) } \\
\text { administration for } 30 \\
\text { days }\end{array}$ & $\begin{array}{l}\text { Male rats, orally intoxicated } \\
\text { with } 10 \mu \mathrm{mol} / \mathrm{kg} \mathrm{Cd}(\mathrm{II}) \\
\text { chloride for } 30 \text { days }\end{array}$ & $\begin{array}{l}\text { The antioxidant reduces the levels of the hepatic } \\
\text { enzymes; MDA, urea and bilirubin. }\end{array}$ & [36] \\
\hline Hesperetin (HTN) & $\begin{array}{l}\text { p.o. in } 0.1 \% \\
\text { carboxymethyl } \\
\text { cellulose }\end{array}$ & $\begin{array}{l}40 \mathrm{mg} / \mathrm{kg} / \text { day for } 21 \\
\text { days }\end{array}$ & $\begin{array}{l}\text { Male rats, intoxicated s.c. for } \\
21 \text { days with } 3 \mathrm{mg} / \mathrm{kg} \text { b.w. } \\
\text { Cd (II) chloride }\end{array}$ & $\begin{array}{l}\text { Hesperetin increases SOD and CAT levels but the } \\
\text { values remain lower than the controls - } 30 \text { and } 15 \% \\
\text { respectively. The hepatic enzymes were partially } \\
\text { recovered. TBARS are affected by HTN but the values } \\
\text { remain higher than the control }(30 \%) \text {. Normal hepatic } \\
\text { architectural pattern with mild dilation of sinusoids in } \\
\text { Cd+HTN treated animals was observed. }\end{array}$ & [24] \\
\hline $\begin{array}{l}\text { Organo- } \\
\text { selenocyanates }\end{array}$ & p.o. & $\begin{array}{l}3 \mathrm{mg} / \mathrm{kg} \text { for } 20 \text { days } \\
\text { applied concomitant or } \\
\text { prior to Cd-intoxication. }\end{array}$ & $\begin{array}{l}\text { Female mice, intoxicated i.p. } \\
\text { with } 2 \mathrm{mg} / \mathrm{kg} \text { Cd(II) chloride } \\
\text { for } 20 \text { days }\end{array}$ & $\begin{array}{l}\text { The tested compounds do not correct SOD level. GSH is } \\
\text { completely recovered by the antioxidants, CAT - } \\
\text { partially (values remain } 10 \% \text { lower than the controls). } \\
\text { TBARS level is } 20 \% \text { higher compared to the controls in } \\
\text { the Cd+antioxidant treated mice. The antioxidants } \\
\text { recover partially the hepatic enzymes. Normal central } \\
\text { vein and hepatocytes structure in antioxidant-treated } \\
\text { animals is observed. }\end{array}$ & [39] \\
\hline Naringenin (NGN) & p.o. & $\begin{array}{l}50 \mathrm{mg} / \mathrm{kg} \text { for } 4 \text { weeks, } \\
\text { administrated together } \\
\text { with Cd(II) }\end{array}$ & $\begin{array}{l}\text { Male rats, orally intoxicated } \\
\text { with Cd(II) }(5 \mathrm{mg} / \mathrm{kg}) \text { for } 4 \\
\text { weeks }\end{array}$ & $\begin{array}{l}\text { NGN recovers the levels of the hepatic and antioxidant } \\
\text { enzymes near to their normal values and preserves the } \\
\text { normal histological architecture. }\end{array}$ & [40] \\
\hline $\begin{array}{l}\text { Naringenin+Vitamin } \\
\text { C+VitaminE }\end{array}$ & p.o. & $\begin{array}{l}50 \mathrm{mg} / \mathrm{kg} \text { for } 28 \text { days of } \\
\text { each compound, } \\
\text { administrated together } \\
\text { with Cd(II) }\end{array}$ & $\begin{array}{l}\text { Male rats, intoxicated orally } \\
\text { with Cd(II) chloride } 5 \mathrm{mg} / \mathrm{kg} \\
\text { b.w. for } 28 \text { days }\end{array}$ & $\begin{array}{l}\text { The combination of three antioxidant results in } \\
\text { complete recovery of SOD, CAT, GSH, TBARS and the } \\
\text { hepatic enzymes. Normal hepatic architecture is } \\
\text { observed in the animals treated with the three } \\
\text { antioxidants. }\end{array}$ & [41] \\
\hline
\end{tabular}

Among the antioxidants, presented in the Table 1, alpha lipoic acid $(\alpha$-LA), curcumin, Mn-curcumin complex, resveratol and melatonin have been shown not to prevent $\mathrm{Cd}-$ accumulation in the liver of Cd-treated animals [25-28].

Alpha lipoic acid $(\alpha$-LA), resveratol and melatonin did not affect Cd-induced decrease of GSH level in the liver, suggesting that these antioxidants might not be the best choice for the treatment of $\mathrm{Cd}$-induced oxidative stress in the liver of animals, subjected to subacute and acute Cd-intoxications [25,28]. Mncurcumin complex recovers GSH level in the liver but the effect of this antioxidant on the trace element homeostasis especially $\mathrm{Fe}$ and $\mathrm{Cu}$ should be taken into account when Mn-curcumin complex is applied for the therapy of Cd-induced hepatotoxicity [27].

Diallyl tetrasulfide [29,30], endomorophin 1 [31], taurine [22] and carnosine [23] have been demonstrated to prevent Cd accumulation in the liver of animals, subjected to acute and subacute Cd-intoxications, as in the case of carnosine administration the effect reaches $87 \%$ compared to the normal control. Considerable improvement of the liver morphology by these antioxidants has been observed.

Vitamin E (applied before Cd-intoxication) has been shown to improve the level of GSH in male rats, subjected to acute intoxication with Cd(II) salt [32]. Panax ginseng, ascorbic acid and garlic also improve the total antioxidant capacity of the liver in Cd-treated animals [33,34]. Detail histological studies about the effect of these antioxidants on the liver morphology of Cd-intoxicated animals are needed to make a conclusion regarding the possible application of these compounds for the treatment of Cd-induced hepatotoxicity.

\subsubsection{Effect of antioxidants on Cd-induced hepatotoxicity in subchronically or chronically Cd-intoxicated animals}

Diphenyl diselenide [36,37], melatonin [38] and hesperetin [24] have been proven to inhibit the level of LPO in the liver of Cd-treated mice. The effect of melatonin [38] however on iron homeostasis should be considered when this antioxidant is utilized for the treatment of Cd-induced hepatotoxicity. Organoselenocyanates [39] have been also effective in restoring the activity of CAT in the liver of Cd-intoxicated animals but the compounds do not recover SOD values. Among the antioxidants screened on animals subchronically or chronically exposed to $\mathrm{Cd}$, naringenin and the combination of naringenin (NGN), vitamin C (Vit C) and vitamin E (Vit E) seem to be the most effective in restoring CAT and SOD activity of the liver (Table 2) [40,41]. Histopathological analysis of the liver of Cd-intoxicated animals treated with the combination of NGN, Vit $C$ and Vit $E$ has revealed that the antioxidants preserve the normal hepatic architecture.

\subsection{Effect of chelating agents on Cd-induced hepatotoxicity in mice, subjected to acute and chronic Cd-intoxication}

A comparative study on the effect of the chelating agents $N$ (4-methylbenzyl)-4-o-(beta- $D$-galactopyranosyl)- $D$-glucamine- 
Table 3. Chelating agents, tested on animal models for the treatment of Cd-induced hepatotoxicity.

\begin{tabular}{|c|c|c|c|c|c|}
\hline Chelating agent & $\begin{array}{l}\text { Route of } \\
\text { administration }\end{array}$ & Dose & Animal model & Effect & Ref. \\
\hline $\begin{array}{l}\text { Mi-ADMS } \\
\text { MeBLDTC }\end{array}$ & $\begin{array}{l}\text { Information not } \\
\text { found }\end{array}$ & $\begin{array}{l}\text { Every } 48 \mathrm{~h} \text { for } 12 \\
\text { days }\end{array}$ & $\begin{array}{l}\text { Male mice, injected i.v. } \\
\text { with Cd(II) chloride }\end{array}$ & $\begin{array}{l}\text { MeBLTDC is more effective on equimolar basis; Mi-ADMS } \\
\text { however could be applied orally. Both compounds improve } \\
\text { trace elements homeostasis in Cd-treated mice. }\end{array}$ & {$[44]$} \\
\hline $\begin{array}{l}\text { DDC, DMDC, } \\
\text { CYCLAM, TACPD, } \\
\text { DMSA, DMPS }\end{array}$ & $\begin{array}{l}\text { Information not } \\
\text { found }\end{array}$ & $\begin{array}{l}\text { Information not } \\
\text { found }\end{array}$ & Mice & $\begin{array}{l}\text { DMDS, CYCLAM, TACPD reduce Cd in the liver, but are not as } \\
\text { effective as DMSA and DMPS. The effect on trace elements is } \\
\text { not studied. }\end{array}$ & [45] \\
\hline $\begin{array}{l}\text { Mi-PDMA; } \\
\text { Mi-BDMA } \\
\text { Mi-ADMA }\end{array}$ & i.p. & $4 \times 1.5 \mathrm{mmol} / \mathrm{kg}$ & $\begin{array}{l}\text { Female rats, exposed to } \\
\text { chronic Cd-intoxication }\end{array}$ & $\begin{array}{l}\text { The effectiveness of the chelating agents increases in the } \\
\text { order: M } i \text {-ADMA }<\text { M } i \text {-BDMA }<\text { M } i \text {-PDMA for the hepatic Cd. } \\
\text { The most effective agent was the most toxic as well. }\end{array}$ & [46] \\
\hline $\begin{array}{l}\text { Carbodithioate } \\
\text { analogue BLDTC } \\
\text { and CaDTPA }\end{array}$ & i.p. & $\begin{array}{l}\text { Injected every } 48 \\
\text { h for } 16 \text { days }\end{array}$ & $\begin{array}{l}\text { Male mice intoxicated with } \\
20 \text { doses of Cd (II) chloride } \\
\text { (single dose of } 3 \mathrm{mg} \mathrm{kg}^{-1} \\
\text { i.p.) }\end{array}$ & $\begin{array}{l}\text { The antidotes restore partially the levels of } \mathrm{Cu} \text { and } \mathrm{Zn} \text {. } \\
\text { BLDTC is more effective than CaDTPA. }\end{array}$ & [49] \\
\hline Monensin & p.o. & $\begin{array}{l}14 \mathrm{mg} / \mathrm{kg} \text {, } \\
\text { applied after Cd- } \\
\text { intoxication }\end{array}$ & $\begin{array}{l}\text { Male mice, subacute } \\
\text { intoxicated with } 20 \mathrm{mg} / \mathrm{kg} \\
\text { Cd (II) acetate for } 14 \text { days }\end{array}$ & $\begin{array}{l}\text { Monensin recovers AST, ALT and ALP values, } \mathrm{Cu} \\
\text { homeostasis. } \mathrm{Zn} \text { homeostasis is partially recovered by the } \\
\text { chelating agent. Monensin reduces Cd concentration in liver } \\
\text { by } 50 \% \text { compared to the toxic control and recovers the } \\
\text { hepatic architecture. }\end{array}$ & {$[47,48]$} \\
\hline
\end{tabular}

Abbreviations: Mi-ADMS: monoisoamyl meso-2,3-dimercaptosuccinate; MeBLDTC: N-(4-methylbenzyl)-4-0-(beta-D-galactopyranosyl)-D-glucamine-Ncarbodithioate; DDC: diethyl dithiocarbamate; DMDC: dimethyl dithiocarbamate; CYCLAM: 1,4,8,11-tetraazacyclotetradecane; TACPD: 1,4,8,12tetraazacyclopentadecane; DMSA: 2,3 dimercaptosuccinic acid; DMPS: 2,3-dimercapto-1-propane sulfonate; Mi-PDMA: meso-2,3-dimercaptosuccinic acid monoisopropylamide; Mi-BDMA: meso-2,3-dimercaptosuccinic acid monoisobutylamide; Mi-ADMA: meso-2,3-dimercaptosuccinic acid monoisoamylamide; BLDTC: N-benzyl-4-O-(beta-D-galactopyranosyl)-D-glucamine-N-carbodithioate CaDTPA: calcium trisodium pentetate.

$N$-carbodithioate (MeBTDTC) and monoisoamyl meso-2,3dimercaptosuccinate (Mi-ADMS) on Cd concentration in Cd-treated animals has demonstrated that the chelating agent MeBTDTC reduces more effectively the concentration of the toxic metal in the liver of animals, subjected to acute Cdintoxication but could not be applied orally in contrast to MiADMS (Table 3) [44].The effect of the chelating agents diethyl dithiocarbamate (DDC), dimethyl dithiocarbamate (DMDC), 1,4,8,11-tetraazacyclotetradecane (CYCLAM), 1,4,8,12-tetraaza cyclopentadecane (TACPD), 2,3-dimercaptosuccinic acid (DMSA), and 2,3-dimercapto-1-propane sulfonate (DMPS) on $\mathrm{Cd}$ concentration in the liver, kidney and brain of mice, exposed to Cd-intoxication has been compared. The results by Srivastava et al. demonstrate that DMSA and DMPS are most effective in reducing $\mathrm{Cd}$ [45], compared to DDC, DMDC, CYCLAM, TACPD. DMSA and DMPS however are hydrophilic compounds and their ability to bind the toxic metal ion, accumulated in the intracellular space is limited.

The meso-2,3-dimercaptosuccinic acid mono- $\mathrm{N}$ alkylamides: Mi-PDMA (meso-2,3-dimercaptosuccinic acid monoisopropylamide); Mi-BDMA (meso-2,3-dimercaptosuccinic acid monoisobutylamide) and Mi-ADMA (meso-2,3dimercaptosuccinic acid monoisoamylamide) are effective in mobilizing $\mathrm{Cd}$ from the liver but are not that much effective in reducing the $\mathrm{Cd}$ concentration in the kidneys. At optimum dose Mi-BDMA reduces renal Cd concentration to $40 \%$ compared to the toxic control [46].

Our studies have demonstrated that the polyether ionophorous antibiotic monensin (applied p.o. as tetraethyl ammonium salt) to mice, subjected to subacute Cd-intoxication reduces the concentration of the toxic metal ion in the liver up to $50 \%$. Furthermore this chelating agent abolished Cdinduced alterations in iron homeostasis and recovered $\mathrm{Cu}$ and Zn levels. The data from the histopathological studies showed that monensin attenuated Cd-induced inflammation in the liver confirming the positive effect of the antibiotic on the liver of mice, exposed to subacute Cd intoxication $[47,48]$.

3. Antioxidants and chelating agents, screened on animal models for the treatment of Cd-induced renal dysfunction

\subsection{Antioxidants}

\subsubsection{Antioxidants, tested on animal models for the treatment of renal dysfunction, induced by subacute and acute Cd-intoxication}

The kidneys are major organs that accumulate metal ions in cases of metal intoxications. $\mathrm{Cd}$ has been shown to induce alterations in creatinine (CR) and urea in the urine and serum of Cd-intoxicated animals [50]. A decrease of the level of the antioxidant enzymes and GSH accompanied with an increase of the LPO in the kidneys of Cd-intoxicated animals has been reported [51,52]. On the morphological level $\mathrm{Cd}$ induces swelling of the epithelial cells of the renal tubules; degeneration and thickening of the basement membrane. Necrosis of the proximal renal tubules has been reported in animals, subjected to acute Cd-intoxication [52]. The antioxidants tested in the period 1992-2012 years for the treatment of Cd-induced renal dysfunction in animals, subjected to acute Cd-intoxication, are presented in Table 4. Diallyl tetrasulfide recovers the level of CR and urea in the serum and urine of Cd-intoxicated rats. The antioxidant has been demonstrated to act as a chelating agent, reducing the concentration of the toxic metal ion by $70 \%$ compared to the normal control [30].

Garlic and onion extracts also effectively restore the total antioxidant capacity of the kidneys of Cd-intoxicated animals [50].

The honey bee, taurine, vitamin $\mathrm{C}$ and isoquercetin have been shown to improve the antioxidant defense in the kidneys of animals, exposed to acute Cd-intoxication [51-53]. Taurine and vitamin $\mathrm{C}$ have been demonstrated to recover CR concentration in the serum of mice, subjected to acute $\mathrm{Cd}$ intoxication. Both antioxidants decrease MDA level, increase GSH and inhibit the accumulation of $\mathrm{Cd}$ in the kidneys. The histopathalogical analysis of kidneys of mice treated with taurine and Vitamin C prior to Cd-intoxication demonstrates that the antioxidants preserve the normal renal architecture. Considering that Vitamin $\mathrm{C}$ is an oral drug it might be the best choice for the treatment of acute Cd-intoxication [52]. Caffeic acid also reduces $\mathrm{Cd}$ in the kidneys of animals, exposed to subacute Cd-intoxication [54].

Analysis of the effect of caffeic acid on Cd-induced elevation of $\mathrm{Zn}$ concentration in kidneys of Cd-treated animals demonstrates that the antioxidant increases $\mathrm{Zn}$ concentration but the values remain lower than the normal controls. 
Table 4. Antioxidants, tested on animal models for the treatment of renal dysfunction induced by acute and subacute Cd-intoxications

\begin{tabular}{|c|c|c|c|c|c|}
\hline Antioxidant & $\begin{array}{l}\text { Route of } \\
\text { administration }\end{array}$ & Dose & Animal model & Effect & Ref. \\
\hline $\begin{array}{l}\text { Diallyl } \\
\text { tetrasulfide } \\
\text { (DTS) }\end{array}$ & p.o. & $\begin{array}{l}40 \mathrm{mg} / \mathrm{kg} \text { b.w./day for } 3 \\
\text { weeks, co-administrated with } \\
\text { Cd(II) }\end{array}$ & $\begin{array}{l}\text { Rats, s.c. intoxicated } \\
\text { with Cd(II) chloride } \\
(3 \mathrm{mg} / \mathrm{kg} / \mathrm{d} \text { for } 3 \\
\text { weeks) }\end{array}$ & $\begin{array}{l}\text { DTS recovers CR and urea in the serum and in urine. DTS } \\
\text { decreases Cd by } 70 \% \text {. DTS also inhibits Cd-induced LPO } \\
\text { and increases GSH and antioxidant enzymes. }\end{array}$ & [30] \\
\hline $\begin{array}{l}\text { Garlic and } \\
\text { onion extract }\end{array}$ & p.o. & $\begin{array}{l}0,5 \mathrm{~mL} / 100 \mathrm{~g} \text { b.w. and } 1 \\
\mathrm{~mL} / 100 \mathrm{~g} \text { b.w. extract prior to } \\
\text { Cd-intoxication. The treatment } \\
\text { continued with Cd(II) } \\
\text { administration. }\end{array}$ & $\begin{array}{l}\text { Rats - intoxicated p.o. } \\
\text { with } 1,5 \mathrm{mg} \mathrm{Cd} / 100 \mathrm{~g} \\
\text { b.w. for } 3 \text { weeks }\end{array}$ & $\begin{array}{l}\text { Both extracts restore the antioxidant defense in the } \\
\text { kidneys but onion is more effective. }\end{array}$ & [50] \\
\hline $\begin{array}{l}\text { Honey bee } \\
\text { (HB) }\end{array}$ & p.o. & $\begin{array}{l}\text { 100; } 250 \mathrm{mg} / \mathrm{kg} \text { b.w., co- } \\
\text { administrated with Cd(II) }\end{array}$ & $\begin{array}{l}\text { Mice, acutely } \\
\text { intoxicated with } \\
\text { Cd(II) chloride - } 2 \\
\text { mg/kg b.w. }\end{array}$ & $\begin{array}{l}\text { Recovery of the GSH level has been observed in the } \\
\text { animals treated with HB accompanied with decrease of } \\
\text { the LPO. }\end{array}$ & [51] \\
\hline $\begin{array}{l}\text { Taurine, } \\
\text { Vitamin C }\end{array}$ & $\begin{array}{l}\text { Taurine -i.p. } \\
\text { Vitamin C - orally }\end{array}$ & $\begin{array}{l}100 \mathrm{mg} / \mathrm{kg} \text { b.w. once daily for } \\
5 \text { days, applied prior to } \\
\text { treatment with Cd(II) }\end{array}$ & $\begin{array}{l}\text { Mice, acutely } \\
\text { intoxicated with } 4 \\
\mathrm{mg} / \mathrm{kg} \text { Cd(II) chloride } \\
\text { (i.p. for } 3 \text { days) }\end{array}$ & $\begin{array}{l}\text { Both antioxidants cause } 50 \% \text { reduction of urea in the } \\
\text { serum and recover CR in the Cd-treated animals. The } \\
\text { antioxidants decrease MDA, but the values remain } 10 \% \\
\text { higher than the control. A } 70 \% \text { decrease of Cd in the } \\
\text { kidneys has been observed as a result of the } \\
\text { administration of the antioxidants. The histological } \\
\text { analysis has been demonstrated normal appearance of } \\
\text { the glomeruli and tubules in the kidneys of Cd-treated } \\
\text { animals, receiving antioxidants. }\end{array}$ & [52] \\
\hline Isoquercetin & $\begin{array}{l}\text { Information not } \\
\text { found }\end{array}$ & Information not found & $\begin{array}{l}\text { Mice, acutely } \\
\text { intoxicated i.p with } \\
\text { Cd(II) chloride - } 2 \\
\text { mg/kg b.w. }\end{array}$ & $\begin{array}{l}\text { The antioxidant has been shown to attenuate Cd-induced } \\
\text { alterations in kidneys and liver. }\end{array}$ & [53] \\
\hline Caffeic acid & i.p., & $\begin{array}{l}10 \mu \mathrm{mol} / \mathrm{kg} \text { per day for } 7 \text { days } \\
\text { coadministrated with Cd(II) }\end{array}$ & $\begin{array}{l}\text { Mice, exposed i.p. to } \\
\text { Cd(II) chloride }(1 \\
\mathrm{mg} / \mathrm{kg} / \text { day for } 7 \\
\text { days) }\end{array}$ & $\begin{array}{l}\text { Caffeic acid completely recovers antioxidant defense } \\
\text { system in the kidneys; reduces Cd level ( } 22 \%) \text {; recovers } \\
\text { partially Zn concentration. Zn concentration remains } 20 \\
\% \text { lower than the control. }\end{array}$ & [54] \\
\hline
\end{tabular}

Table 5. Antioxidants, applied for the treatment of Cd-induced oxidative stress in the kidneys of animals, subjected to subchronic and chronic Cd-intoxications.

\begin{tabular}{|c|c|c|c|c|c|}
\hline Antioxidant & $\begin{array}{l}\text { Route of } \\
\text { administration }\end{array}$ & Dose & Animal model & Effect & Ref. \\
\hline $\begin{array}{l}\text { Glycyrrhizin, } \\
\text { cysteine, } \\
\text { glycine }\end{array}$ & $\begin{array}{l}\text { Information not } \\
\text { found }\end{array}$ & Information not found & $\begin{array}{l}\text { Rats, subjected to } \\
\text { chronic intoxication } \\
\text { with } 5 \mu \mathrm{M} \mathrm{Cd}(\mathrm{II}) \\
\text { chloride } / \mathrm{kg} \text { b.w. } / \text { day } \\
5 \text { times a week for } 22 \\
\text { weeks }\end{array}$ & The antioxidants reduce chronic Cd-toxicity. & [62] \\
\hline Melatonin & p.o & $\begin{array}{l}4 \mu \mathrm{g} / \mathrm{mL} \text { (optimum dose) for } 8 \\
\text { weeks applied together with } \\
\text { Cd(II) }\end{array}$ & $\begin{array}{l}\text { Female and male, } \\
\text { subchronically } \\
\text { intoxicated with } 50 \\
\mu \mathrm{g} \mathrm{Cd} / \mathrm{mL} \text { as Cd(II) } \\
\text { chloride for } 8 \text { weeks }\end{array}$ & $\begin{array}{l}\text { Melatonin decreases Cd level by } 23 \% \text { compared to toxic } \\
\text { control; the antioxidant however decreases hepatic iron } \\
\text { to } 14 \% \text { compared to the toxic control. The Cd-induced } \\
\text { alteration in Fe homeostasis was not recovered by the } \\
\text { antioxidant. }\end{array}$ & [38] \\
\hline $\begin{array}{l}\text { Quercetin } \\
\text { (QE) }\end{array}$ & i.p. & $\begin{array}{l}50 \mathrm{mg} / \mathrm{kg} / \text { day for } 9 \text { weeks } \\
\text { along with Cd(II) }\end{array}$ & $\begin{array}{l}\text { Rats, intoxicated s.c. } \\
1.2 \mathrm{mg} / \mathrm{kg} / \text { day Cd(II) } \\
\text { for } 9 \text { weeks }\end{array}$ & $\begin{array}{l}\text { QE prevents Cd-induced overexpression of iNOS and } \\
\text { COX- } 2 \text {. }\end{array}$ & [58] \\
\hline $\begin{array}{l}\mathrm{N}- \\
\text { acetylcysteine } \\
\text { (NAC) }\end{array}$ & p.o. & $\begin{array}{l}0,5 \% \text { when applied together } \\
\text { with Cd; } 2 \% \text { when used after } \\
\text { intoxication. The antioxidant } \\
\text { has been applied in co- } \\
\text { administration with cadmium } \\
\text { and after the intoxication }\end{array}$ & $\begin{array}{l}\text { Rats, intoxicated with } \\
\mathrm{CdCl}_{2} \text { for } 3 \text { months }\end{array}$ & $\begin{array}{l}\text { NAC recovers SOD and CAT. GSH is no affected by the } \\
\text { antioxidant. In both cases NAC preserves the normal } \\
\text { appearance of the renal proximal tubules }\end{array}$ & [55] \\
\hline NAC & p.o. & $120 \mathrm{mg} / \mathrm{kg} /$ day & $\begin{array}{l}\text { Female rats, } \\
\text { chronically exposed } \\
\text { to } 20 \mathrm{mg} / \mathrm{L} \mathrm{Cd}(\mathrm{II})\end{array}$ & $\begin{array}{l}\text { NAC decreases LPO, but the concentration of Cd in the } \\
\text { kidney is not affected. GSH, SOD and CAT have not been } \\
\text { recovered by the antioxidant. }\end{array}$ & [56] \\
\hline $\begin{array}{l}\text { Naringenin } \\
\text { (NGN) }\end{array}$ & p.o. & $\begin{array}{l}50 \mathrm{mg} / \mathrm{kg} / \text { day for } 4 \text { weeks, } \\
\text { together with Cd(II) } \\
\text { administration }\end{array}$ & $\begin{array}{l}\text { Rats, exposed to } \\
\text { subchronic } \\
\text { intoxication with } \\
\text { Cd(II) chloride } 5 \\
\mathrm{mg} / \mathrm{kg} \text { for } 4 \text { weeks }\end{array}$ & $\begin{array}{l}\text { NGN preserves Cd-induced alterations in the antioxidant } \\
\text { enzymes; GSH and LPO. NGN ameliorates Cd-induced } \\
\text { alterations in the renal architecture. }\end{array}$ & [57] \\
\hline QE & p.o. & $\begin{array}{l}50 \mathrm{mg} / \mathrm{kg} / \text { day for } 4 \text { weeks, co- } \\
\text { administrated with Cd(II) }\end{array}$ & $\begin{array}{l}\text { Rats, exposed to } \\
\text { subchronic } \\
\text { intoxication with } \\
\text { Cd(II) chloride } 5 \\
\mathrm{mg} / \mathrm{kg} \text { for } 4 \text { weeks, } \\
\text { co-administrated } \\
\text { with Cd(II) }\end{array}$ & $\begin{array}{l}\text { QE recovers CR and urea and attenuates Cd-induced } \\
\text { alterations in the antioxidant status in the kidneys; QE } \\
\text { ameliorates Cd-induced pathology of the kidneys. }\end{array}$ & [59] \\
\hline $\begin{array}{l}\text { QE; Vitamin C } \\
\text { and Vitamin E }\end{array}$ & p.o. & Information not found & Rats & $\begin{array}{l}\text { The combination of } \mathrm{QE} \text { plus vitamin } \mathrm{C} \text { and vitamin } \mathrm{E} \\
\text { improves the renal morphology and attenuates } \mathrm{Cd} \text { - } \\
\text { induced alterations in antioxidant defence system. }\end{array}$ & [60] \\
\hline Telmisartan & p.o. & $\begin{array}{l}1 \mathrm{mg} / \mathrm{kg} / \text { daily started one } \\
\text { week before Cd administration } \\
\text { and continued for } 10 \text { weeks }\end{array}$ & $\begin{array}{l}\text { Mice, treated with } 1.2 \\
\mathrm{mg} \mathrm{Cd} / \mathrm{kg} \text { day for } 9 \\
\text { weeks }\end{array}$ & $\begin{array}{l}\text { The antioxidant improves } \mathrm{Zn} \text { homeostasis, decreases the } \\
\text { concentration of Cd and inhibits the LPO. Telmisaran also } \\
\text { decreases TNF-a and NO elevated by Cd. }\end{array}$ & [63] \\
\hline $\begin{array}{l}\text { Herbal } \\
\text { adaptogens }\end{array}$ & $\begin{array}{l}\text { p.o. after Cd- } \\
\text { intoxication }\end{array}$ & $\begin{array}{l}0,1 \% \text { powder in the feed, } \\
\text { applied for } 2 \text { weeks }\end{array}$ & $\begin{array}{l}\text { Chicks, exposed to } \\
\text { chronic cadmium } \\
\text { intoxication } 100 \\
\text { ppm/ day for } 28 \text { days }\end{array}$ & $\begin{array}{l}\text { Asperagus recemosus, Angrographis paniculata are most } \\
\text { effective among eight adaptogens tested. These } \\
\text { adaptogens recover GSH; reduce LPO to normal values } \\
\text { and decrease Cd in the kidneys by } 50 \% \text {. The serum CR } \\
\text { however remains higher than the normal control. }\end{array}$ & [61] \\
\hline
\end{tabular}


Table 6. Chelating agents, screened on animal models for mobilization of Cd in kidneys.

\begin{tabular}{|c|c|c|c|c|c|}
\hline Chelating agent & $\begin{array}{l}\text { Administration } \\
\text { route }\end{array}$ & Dose & Animal model & Effect & Ref. \\
\hline $\begin{array}{l}\text { MPhEDMS } \\
\text { MPhPDMS } \\
\text { MPhOEDMS }\end{array}$ & i.p. & $\begin{array}{l}0,5 \mathrm{mmol} / \mathrm{kg} / \mathrm{day} \\
\text { for } 4 \text { days }\end{array}$ & Rats & $\begin{array}{l}\text { The chelating agents significantly deplete hepatic and } \\
\text { renal Cd compared with the toxic control }\end{array}$ & [64] \\
\hline MBzDMS & i.p.; i.v.; p.o. & & Rats/mice & $\begin{array}{l}\text { MBzDMS was found to be less effective than Mi-ADMS in } \\
\text { mobilizing Cd. }\end{array}$ & [68] \\
\hline $\begin{array}{l}\text { TRIEN, TREN, } \\
\text { TETREN, PENTEN }\end{array}$ & & & $\begin{array}{l}\text { Rats, intoxicated with } \\
\text { Cd } 4 \text { days before } \\
\text { chelation }\end{array}$ & The chelating agents cause significant renal damage. & [65] \\
\hline $\begin{array}{l}\text { Mi-PDMA; } \\
\text { Mi-BDMA } \\
\text { Mi-ADMA }\end{array}$ & i.p. & $4 \times 1.5 \mathrm{mmol} / \mathrm{kg}$ & $\begin{array}{l}\text { Famale rats, exposed } \\
\text { to chronic Cd- } \\
\text { intoxication }\end{array}$ & $\begin{array}{l}\text { The chelating agents do not possess optimized structure } \\
\text { between LD50 and effectiveness. }\end{array}$ & [46] \\
\hline $\begin{array}{l}\text { DDC, DMDC, CYCLAM, } \\
\text { TACPD, DMSA, DMPS }\end{array}$ & $\begin{array}{l}\text { Information not } \\
\text { found }\end{array}$ & $\begin{array}{l}\text { Information not } \\
\text { found }\end{array}$ & Mice & $\begin{array}{l}\text { DMDS, CYCLAM, TACPD reduce Cd in the kidneys. The } \\
\text { therapeutic index of the chelating agents decreases in the } \\
\text { order: DMSA }>\text { DMPS }>\text { DMDC }\end{array}$ & [45] \\
\hline MFA; MSFA; MAFA & $\begin{array}{l}\text { Information not } \\
\text { found }\end{array}$ & $\begin{array}{l}\text { Information not } \\
\text { found }\end{array}$ & Rats & $\begin{array}{l}\text { The chelating agents affect the trace elements } \\
\text { homeostasis. }\end{array}$ & [66] \\
\hline Diethylcarbamate & p.o. & $100 \mathrm{mg} / \mathrm{kg}$ b.w. & $\begin{array}{l}\text { Rats, subjected to } \\
\text { acute intoxication } \\
\text { with } \mathrm{Cd} \text { for } 60 \text { days } \\
\text { ( } 40 \mathrm{mg} / \mathrm{kg} / \text { day) }\end{array}$ & The chelating agent reduces $\mathrm{Cd}$ in kidney by $60 \%$. & [69] \\
\hline DFO & p.o. & $\begin{array}{l}\text { Information not } \\
\text { found }\end{array}$ & $\begin{array}{l}\text { Rats, subjected to } \\
\text { acute intoxication } \\
\text { with Cd for } 60 \text { days } \\
\text { ( } 20 \text { and } 40 \\
\mathrm{mg} / \mathrm{kg} / \text { day) }\end{array}$ & $\begin{array}{l}\text { DFO improves Fe homeostasis and reduces } \mathrm{Cd} \text { in the } \\
\text { body. }\end{array}$ & [67] \\
\hline Monensin & p.o. & $14 \mathrm{mg} / \mathrm{kg}$ & $\begin{array}{l}\text { Mice, subjected to } \\
\text { subactute Cd } \\
\text { intoxication for } 2 \\
\text { weeks }\end{array}$ & $\begin{array}{l}\text { Monensin improves iron homeostasis and reduces Cd } \\
\text { from } 50 \% \text { (liver) to } 90 \% \text { (heart). }\end{array}$ & [47] \\
\hline
\end{tabular}

It should be pointed out that in contrast to the antioxidants discussed above the caffeic acid has been applied i.p., therefore it might not be the best choice for the treatment of Cdintoxication [54].

\subsubsection{Antioxidants, tested on animal models for the treatment of renal dysfunction, induced by subchronic and chronic Cd-intoxications}

The antioxidants screened on animals, exposed to subchronic and chronic Cd-intoxications, are summarized in Table 5 .

$\mathrm{N}$-acetylcysteine (NAC) salt is effective in improving renal function of male and female rats, exposed to chronic $\mathrm{Cd}$ intoxication. In both cases however NAC does not recover GSH $[55,56]$.

Naringenin (NGN), Quercetin (QE), QE+Vitamin C+Vitamin $\mathrm{E}$ have been demonstrated to recover $\mathrm{CR}$ and urea levels in serum and urine in animals, subjected to subchronic Cdintoxication [57-60]. Furthermore, these antioxidants decrease LPO in the kidneys and improve GSH and antioxidant enzymes levels. The histopatological analysis of the renal tissue of $\mathrm{Cd}$ treated animals, receiving $\mathrm{NGN}$ or $\mathrm{QE}$ reveals that these antioxidants preserve the normal renal architecture [57-60].

The herbal adaptogens: Withania somnifera, Ocimum sanctum, Asperagus recemosus, Andrographis paniculata, Asphaltum panjabinum (Shilajith), Gymnema sylvestre, Spirulina platensis, and Panex ginseng have been tested to prevent Cd bioaccumulation in chicks, exposed to chronic Cdintoxication [61]. The herbal adaptogens Asperagus recemosus and Andrographis paniculata, applied p.o., reduce $\mathrm{Cd}$ concentration in kidney by $50 \%$ compared to the control; inhibit LPO, and recover GSH level. CR values in the serum of Cd-treated animals, receiving antioxidants, however remain higher than the normal control (25\%) [61]

\subsection{Chelating agents}

The monoaralkyl esters (HOOCCH(SH)CH(SH)COOR, where $\mathrm{R}=$ phenylethyl $\left(\left(\mathrm{CH}_{2}\right)_{2} \mathrm{C}_{6} \mathrm{H}_{5}\right)$, MPhEDMS; $\mathrm{R}=3$-phenylpropyl $\left(\left(\mathrm{CH}_{2}\right)_{3} \mathrm{C}_{6} \mathrm{H}_{5}\right)$, MPhPDMS; and $\mathrm{R}=2$-phenoxyethyl $\left(\left(\mathrm{CH}_{2}\right)_{2} \mathrm{OC}_{6} \mathrm{H}_{5}\right)$. MPhOEDMS) of meso-2,3-dimercaptusuccinic acid have been effective in reducing the hepatic and renal $\mathrm{Cd}$ concentration in Cd-intoxicated rats, but no information regarding the effect of the chelating agents on the trace elements homeostasis has been presented. Furthermore, the esters of DMSA have been administrated i.p., which could be a disadvantage of these agents over others chelators for the treatment of Cd-intoxication (Table 6) [64].

Among the chelating agents, the polyamines: triethylenetetraamine dihydrochloride (TRIEN), tris(2-amino ethyl)amine trihydrochloride (TREN), tetraethylene pentamine pentahydrochloride (TETRAEN), and pentaethylene hexamine hexahydrochloride (PENTAEN) increase $\mathrm{Cd}$ in the urine of Cdexposed rats (Table 5) [65]. Oliguria and anuria induced as a result of the application of these chelating agents have been observed in Cd-treated animals, suggesting a significant renal damage [65].

DMSA and DMPS reduce Cd in the kidneys of mice, exposed to $\mathrm{Cd}$ intoxication, but DMSA is not effective in eliminating $\mathrm{Cd}$ from intracellular deposits. Therefore this agent is not very suitable for the treatment of chronic Cd-intoxication [46].

The chelating agents alpha-mercapto-beta-(2-furyl) acrylic acid (MFA), alpha-mercapto-beta-(5-sodiumsulfonate, 2-furyl) acrylic acid (MSFA) and alpha-mercapto-beta-(5-acetoxy methyl, 2-furyl) acrylic acid (MAFA) have been found to be effective in mobilizing $\mathrm{Cd}$ in Cd-treated animals, but their affect on trace element homeostasis, especially $\mathrm{Cu}$ and $\mathrm{Zn}$, should be considered in chelation therapy with these agents [66]. 
Table 7. Antioxidants, tested on animal models for the treatment of Cd-induced toxicity in the testes (acute Cd-intoxication).

\begin{tabular}{|c|c|c|c|c|c|}
\hline Antioxidant & $\begin{array}{l}\text { Route of } \\
\text { administration }\end{array}$ & Dose & Animal model & Effect & Ref. \\
\hline $\begin{array}{l}\text { Ascorbic } \\
\text { acid }\end{array}$ & p.o. & $200 \mathrm{mg} / 100 \mathrm{~g}$ b.w. & $\begin{array}{l}\text { Rats, exposed to acute } \\
\text { intoxication with } 0.2 \text { and } \\
0.3 \mathrm{mg} / 100 \mathrm{~g} \text { b.w. } \mathrm{Cd}(\mathrm{II}) \\
\text { (s.c.) }\end{array}$ & $\begin{array}{l}\text { The antioxidant prevents germ cell apoptosis; } \\
\text { restores testosterone; 3-beta and 17-beta HSD. }\end{array}$ & {$[71,72]$} \\
\hline $\begin{array}{l}\text { Vitamin C } \\
\text { Vitamin E }\end{array}$ & i.p. & $\begin{array}{l}\text { Vitamin C } 10 \mathrm{mg} / \mathrm{kg} \text { b.w.; } \\
\text { Vitamin E - } 100 \mathrm{mg} / \mathrm{kg} \text { b.w., } \\
\text { concurrent with Cd(II) }\end{array}$ & $\begin{array}{l}\text { Mice, intoxicated with } \\
\text { Cd(II) chloride } 1 \mathrm{mg} / \mathrm{kg} \\
\text { b.w. i.p. }\end{array}$ & $\begin{array}{l}\text { Both vitamins improve sperm count, decrease sperm } \\
\text { abnormality percentage and partially improve total } \\
\text { antioxidant capacity in the testes. }\end{array}$ & [73] \\
\hline Hemin & p.o. & $\begin{array}{l}40 \mu \mathrm{mol} / \mathrm{kg} \text { b.w., applied one } \\
\text { day before Cd-intoxication and } \\
\text { continued for } 2 \text { days after Cd- } \\
\text { administration }\end{array}$ & $\begin{array}{l}\text { Rats, exposed to acute } \\
\text { intoxication with } 2 \mathrm{mg} / \mathrm{kg} \\
\text { Cd(II) chloride, i.p. }\end{array}$ & $\begin{array}{l}\text { Hemin restores the active spermatogenesis but the } \\
\text { values of testosterone remain lower than the normal } \\
\text { control. The antioxidant preserves the normal } \\
\text { histoarchitectute of the testes of Cd-treated rats. }\end{array}$ & [74] \\
\hline$(\mathrm{PhSe})_{2}$ & p.o. & $\begin{array}{l}400 \mu \mathrm{mol} / \mathrm{kg} \text { b.w., applied } 30 \\
\text { min after Cd-administration }\end{array}$ & $\begin{array}{l}\text { Mice, exposed to Cd(II) } \\
\text { chloride } \\
\text { ( } 5 \mathrm{mg} / \mathrm{kg} \text { b.w., i.p.) }\end{array}$ & $\begin{array}{l}\text { The antioxidant partially decreases Cd-induced LPO } \\
\text { and increases ascorbic acid in the testes. Moderate } \\
\text { edema is observed in the testicular tissues of Cd- } \\
\text { treated animals, receiving }(\mathrm{PhSe})_{2} \text {. }\end{array}$ & [75] \\
\hline $\begin{array}{l}\text { Vitamin E } \\
\text { and Q10 }\end{array}$ & $\begin{array}{l}\text { Information not } \\
\text { found }\end{array}$ & Information not found & $\begin{array}{l}\text { Rats, exposed to } 0,4 \\
\mathrm{mg} / \mathrm{kg}\end{array}$ & $\begin{array}{l}\text { Both antioxidants recover GSH, SOD and GR and } \\
\text { GSH-Px to normal values. }\end{array}$ & [76] \\
\hline Melatonin & i.p. & $\begin{array}{l}5 \mathrm{mg} / \mathrm{kg} \text { b.w. every } 8^{\text {th }} \text { hour, } \\
\text { beginning } 8 \text { hours before Cd- } \\
\text { administration }\end{array}$ & $\begin{array}{l}\text { Mice, exposed to Cd(II) } \\
\text { chloride }(2 \mathrm{mg} / \mathrm{kg}) \text {, i.p. }\end{array}$ & $\begin{array}{l}\text { The antioxidant inhibits Cd-induced testicular germ } \\
\text { cell apoptosis. }\end{array}$ & [77] \\
\hline
\end{tabular}

DFO and monensin are most effective in the elimination of $\mathrm{Cd}$ in animals, exposed to acute and subactute Cd-intoxication. Both agents have been demonstrated to improve iron homeostasis and could be applied orally [46,67].

\section{Antioxidant and chelating agents, tested on animal models for the treatment of Cd-induced testicular dysfunction}

Cd induces reduction of sperm motility, testosterone, $3-\beta$ hydroxysteroiddehydrogenase (3- $\beta$-HSD), 17- $\beta$-hydroxysteroid dehydrogenase (17- $\beta$-HSD) and an increase of the percentage of abnormal sperm in animals, subjected to $\mathrm{Cd}$ intoxication. Histopathological analysis of testicular tissue of animals, administrated $\mathrm{Cd}$, reveals that the toxic metal causes severe lesions in the form of diffuse necrosis affecting the germinal layer in the seminiferous tubules and interstitial tissue [70]. Higher levels of lipid peroxidation in testes compared to the normal control have been reported in animals, receiving $\mathrm{Cd} . \mathrm{Cd}$ decreases the activity of antioxidant enzymes: SOD, CAT and GSH level in the testes [70].

\subsection{Antioxidants}

\subsubsection{Antioxidants, screened on animal models for the treatment of oxidative stress in testes of animals, exposed to acute Cd-intoxication}

The antioxidants, screened on animal models for the treatment of oxidative stress in testes of animals, exposed to acute Cd-intoxication, are summarized in Table 7. Vitamins C and $\mathrm{E}$ alone or in combination, applied concurrent with $\mathrm{Cd}$ intoxication have been shown to restore testosterone and testicular key androgenic enzymes 3- $\beta$-hydroxysteroid dehydrogenase and 17- $\beta$-hydroxysteroid dehydrogenase $[71,72]$. Depending on the dose of Cd, Vitamins $C$ and $E$ have been demonstrated to recover partially or completely the total antioxidant capacity in the testes. Both vitamins decrease sperm abnormality percentage and improve sperm count [71$73,76]$.

\subsubsection{Antioxidants, screened on animals for the treatment of oxidative stress in testes of animals, exposed to subchronic and chronic Cd-intoxication}

The antioxidants tested on Cd-induced oxidative stress in animals, exposed to subchronic and chronic Cd intoxication, are presented in Table 8.
Vitamin $\mathrm{E}$ and $\beta$-carotene improve some hematological paramets (Hb, TEC, TLC) in rats, subjected to subchronic Cdintoxication and significantly recover sperm quality $[80,81]$. $\alpha$ tocopherol reduces the degree of necrosis of the seminiferous tubules induced by $2 \mathrm{mg} / \mathrm{kg}$ b.w. Cd(II) chroride, injected i.p. in rats for 5 weeks $[78,79]$. The antioxidant however has been demonstrated not to have protective effect in higher doses of Cd(II) chloride [80] and applied before Cd-intoxication.

$\alpha$-Lipoic acid, applied along with $\mathrm{Cd}$, also recovers testicular key androgenic enzymes and preserves the normal testicular architecture [81].

Among the antioxidants, screened on animal models for the treatment of Cd-induced toxicity in the testes of animals exposed to subchronic or chronic Cd-intoxication, hesperetin (HP), diallyl tetrasulfide (DTS) and $\alpha$-tocopherol possess chelating effect, reducing the concentration of toxic metal ion [70,82-84]. The protection by these antioxidants is further substantiated by reduction of $\mathrm{Cd}$-induced pathological changes in the testicular tissue.

\subsection{Chelating agents}

The chelating agents screened on animal models for the treatment of Cd-induced toxicity in testes are summarized in Table 9. Diethyldithiocarbamate (DED) alone decreases Cd concentration in testes, but redistribution of the toxic metal ion to the kidneys and brain has been observed [91,92]. The combinations of DED and $N$-benzyl- $D$-glucamine dithio carbamate (BGD) or DED and $N$ - $p$-isopropylbenzyl- $D$ glucaminedithiocarbamate (PBGD) diminish Cd level in testes without causing its redistribution in other tissues [91,92] However, these combinations of the chelating agents increase $\mathrm{Cd}$ concentration in the blood and Cd distribution in the red blood cells [91,92]. Disulfiram (DSF) has been demonstrated to be more effective compated to DED in reducing the testicular damage, caused by $\mathrm{Cd}$ [93].

Meso-2,3-dimercaptosuccinic acid (DSMA) applied alone or in combination with (PhSe $)_{2}$ inhibits the toxicity caused by 2.5 $\mathrm{mg} / \mathrm{kg}$ b.w. Cd(II) chloride in mice. Both compounds however are ineffective in restoring the SOD activity and the level of ascorbic acid, induced by $5 \mathrm{mg} / \mathrm{kg}$ Cd(II) chloride [94] Diphenyl diselenide applied s.c. 30 min after Cd administration in mice elevates Cd-induced injury in the testes, but when administrated at higher dose $(100 \mu \mathrm{mol} / \mathrm{kg})$, applied alone or together with 2,3-dimercapto-1-propanesulfonic acid (DMPS) decreases Cd-induced toxicity and improves the level of $\delta$ aminolevulinic acid dehydratase $(\delta$-ALA-D) $[95,96]$. 
Table 8. Antioxidants, screened on animal models for the treatment of Cd-induced oxidative stress in testes of animals, exposed to subchonic and chronic Cdintoxication.

\begin{tabular}{|c|c|c|c|c|c|}
\hline Antioxidant & $\begin{array}{l}\text { Route of } \\
\text { administration }\end{array}$ & Dose & Animal model & Effect & Ref. \\
\hline$\beta$-carotene & i.g. & $\begin{array}{l}250 \mathrm{IU} / \mathrm{kg} \text {, concurrent with } \\
\mathrm{Cd}(\mathrm{II})\end{array}$ & $\begin{array}{l}\text { Rats, intoxicated with } \\
\text { Cd(II) chloride } \\
(2 \mathrm{mg} / \mathrm{kg} \text { b.w. - } \\
\text { intragastrically for } 3 \text { and } 6 \\
\text { weeks) }\end{array}$ & $\begin{array}{l}\text { The antioxidant restores the activity of SOD and GSH } \\
\text { in the testes and brain. }\end{array}$ & [78] \\
\hline $\begin{array}{l}\text { Vitamin E-, } \\
\beta \text {-carotene }\end{array}$ & p.o. by gavage & $\begin{array}{l}100 \mathrm{mg} / \mathrm{kg} \text { Vitamin } \mathrm{E} ; 10 \\
\mathrm{mg} / \mathrm{kg} \beta \text {-carotene for } 15 \text { days, } \\
\text { concurrent with Cd(II) }\end{array}$ & $\begin{array}{l}\text { Rats, exposed to } \mathrm{Cd}(\mathrm{II}) \\
\text { chloride } \\
\text { (5mg/kg b.w. for } 15 \text { days }\end{array}$ & $\begin{array}{l}\text { Both vitamins alone or in combination improve } \\
\text { sperm concentration, motility (\%) and recover the } \\
\text { weight of the testes and epididymis, and decrease } \\
\text { the abnormal sperm. }\end{array}$ & [79] \\
\hline$\alpha$-tocopherol & i.p. & $\begin{array}{l}0,1 \mathrm{~mL} \text { applied five days before } \\
\text { Cd-intoxication }\end{array}$ & $\begin{array}{l}\text { Rats, exposed to Cd i.p. } \\
\text { Doses of Cd(II) chloride - } \\
1,2,4,9 \mathrm{mg} / \mathrm{kg} \text { b.w. for } 5 \\
\text { weeks }\end{array}$ & $\begin{array}{l}\text { The antioxidant does not show protective effect on } \\
\text { higher doses of } \mathrm{Cd}(\mathrm{II}) \text { chloride }-4 \text { and } 8 \mathrm{mg} / \mathrm{kg} \text {. }\end{array}$ & {$[80]$} \\
\hline $\begin{array}{l}\text { Organoseleniu } \\
\text { m compound } \\
\text { (Ebselen) }\end{array}$ & $\begin{array}{l}\text { Information not } \\
\text { found }\end{array}$ & Information not found & $\begin{array}{l}\text { Mice, administrated i.p. } \\
\text { Cd(II) chloride }\end{array}$ & $\begin{array}{l}\text { Ebselen recovers the levels of ascorbic acid; the } \\
\text { activity of delta-ALA-D and inhibits LPO in the } \\
\text { testes. }\end{array}$ & [85] \\
\hline $\begin{array}{l}\text { Diallyl } \\
\text { sulphide } \\
\text { (DAS) }\end{array}$ & $\begin{array}{l}\text { Information not } \\
\text { found }\end{array}$ & Information not found & $\begin{array}{l}\text { Rats, exposed to } 2,5 \\
\mathrm{mg} / \mathrm{kg} \text { Cd(II) chloride five } \\
\text { times a week for } 4 \text { weeks }\end{array}$ & $\begin{array}{l}\text { DAS restores total antioxidant capacity in the testes } \\
\text { and restores testosterone levels; } 3 \text {-beta-HSD and } 17 \text { - } \\
\text { beta-HSD. }\end{array}$ & [86] \\
\hline $\begin{array}{l}\text { Onion and } \\
\text { garlic }\end{array}$ & p.o. & $\begin{array}{l}0,5 \mathrm{~mL} / 100 \mathrm{~g} \text { bw. } \\
1 \mathrm{~mL} / 100 \mathrm{~g} \text { b.w.; applied } 1 \\
\text { week before intoxication and } \\
\text { continued with Cd- } \\
\text { administration }\end{array}$ & $\begin{array}{l}\text { Rats, intoxicated with } 1,5 \\
\mathrm{mg} \mathrm{Cd} / 100 \mathrm{~g} \text { b.w. daily } \\
\text { p.o. for } 3 \text { weeks }\end{array}$ & $\begin{array}{l}\text { The onion and combination of onion and garlic are } \\
\text { more effective than garlic alone. The antioxidants } \\
\text { improve sperm motility, decrease abnormal sperm } \\
\text { rate. They partially recovered GSH, SOD and reduce } \\
\text { LPO. }\end{array}$ & [87] \\
\hline$\alpha$-lipoic acid & p.o. & $\begin{array}{l}35 \mathrm{mg} / \mathrm{kg} \text {, concurrent with } \\
\mathrm{Cd}(\mathrm{II})\end{array}$ & $\begin{array}{l}\text { Rats, exposed to } 2 \mathrm{mg} / \mathrm{kg} \\
\text { Cd(II) chloride, i.p. for } 28 \\
\text { days }\end{array}$ & $\begin{array}{l}\text { The antioxidant ameliorates testicular key } \\
\text { androgenic enzymes and preserves the normal } \\
\text { histoarchitecture of the testes. }\end{array}$ & [81] \\
\hline $\begin{array}{l}\text { Guarana } \\
\text { (Paullinia } \\
\text { cupana) }\end{array}$ & p.o. or i.p. & $\begin{array}{l}\text { Pretreatment for } 56 \text { days with } \\
2 \mathrm{mg} / \mathrm{kg} \text { b.w., } 1.15 \mathrm{mg} / \mathrm{kg} \text { i.p. } \\
\text { single dose }\end{array}$ & Rats & $\begin{array}{l}\text { P. Cupana reduces inflammatory cell response and } \\
\text { improves the morphology of Leidyg cells. }\end{array}$ & [88] \\
\hline $\begin{array}{l}\text { Tribulus } \\
\text { terrestris Linn } \\
\text { (TT); } \alpha- \\
\text { tocopherol }\end{array}$ & p.o. & $\begin{array}{l}\text { TT - } 5 \mathrm{mg} / \mathrm{kg} \text { b.w. daily; 目- } \\
\text { tocopherol - } 75 \mathrm{mg} / \mathrm{kg} \text { b.w. } \\
\text { daily for } 6 \text { weeks }\end{array}$ & $\begin{array}{l}\text { Rats, exposed to Cd(II) } \\
\text { chloride treatment ( } 3 \\
\mathrm{mg} / \mathrm{kg} \text { b.w.) once a week } \\
\text { for } 6 \text { weeks }\end{array}$ & $\begin{array}{l}\text { TT reduces Cd by } 50 \%, \alpha \text {-tocopherol - } 80 \% \text {. Both } \\
\text { antioxidants improve total antioxidant capacity of } \\
\text { the testes and preserve the normal histoarchitecture } \\
\text { of the testes. The } \alpha \text {-tocopherol is more effective than } \\
\text { TT at the doses applied. }\end{array}$ & {$[82,83]$} \\
\hline $\begin{array}{l}\text { Quercetin } \\
\text { (QE) }\end{array}$ & p.o. & $\begin{array}{l}75 \mathrm{mg} / \mathrm{kg} \text { daily for } 2 \text { weeks, } \\
\text { concurrent with Cd(II) }\end{array}$ & $\begin{array}{l}\text { Mice, treated with } \mathrm{Cd}(\mathrm{II}) \\
\text { chloride }(4 \mathrm{mg} / \mathrm{kg} \text { b.w.) } \\
\text { p.o. for } 2 \text { weeks }\end{array}$ & $\begin{array}{l}\text { The antioxidant inhibits germ cell apoptosis and LPO } \\
\text { induced by Cd. QE recovers SOD and improves GSH } \\
\text { level. }\end{array}$ & [89] \\
\hline Ginger & p.o. & Information not found & Rats & $\begin{array}{l}\text { The antioxidant reverses the Cd-induced toxicity in } \\
\text { the testes. }\end{array}$ & [90] \\
\hline $\begin{array}{l}\text { Hesperetin } \\
\text { (HP) }\end{array}$ & p.o. & $\begin{array}{l}40 \mathrm{mg} / \mathrm{kg} \text { b.w. along with } \\
\mathrm{Cd}(\mathrm{II})\end{array}$ & $\begin{array}{l}\text { Rats, intoxicated with } 3 \\
\mathrm{mg} / \mathrm{kg} \text { b.w. Cd (II) } \\
\text { chloride s.c. for } 21 \text { days }\end{array}$ & $\begin{array}{l}\text { HP reduces } \mathrm{Cd} \text { concentration in the testes by } 50 \% \text {; } \\
\text { abolishes Cd-induced pathology in testicular tissue } \\
\text { and improves the antioxidant total capacity. }\end{array}$ & [70] \\
\hline $\begin{array}{l}\text { Diallyl } \\
\text { tetrasulfide } \\
\text { (DTS) }\end{array}$ & p.o. & $\begin{array}{l}40 \mathrm{mg} / \mathrm{kg} \text { b.w. concurrent with } \\
\text { Cd(II) }\end{array}$ & $\begin{array}{l}\text { Male rats, intoxicated with } \\
3 \mathrm{mg} / \mathrm{kg} \mathrm{Cd} \text { s.c. for } 3 \\
\text { weeks }\end{array}$ & $\begin{array}{l}\text { DTS reduces Cd accumulation in the testes, improves } \\
\text { the activity of antioxidant enzymes and GSH level in } \\
\text { the testes, and preserves the normal } \\
\text { histoarchitecture of the testes. }\end{array}$ & [84] \\
\hline
\end{tabular}

Table 9. Chelating agents, applied for treatment of Cd concentration in testes of animals, subjected to Cd-intoxication.

\begin{tabular}{|c|c|c|c|c|c|}
\hline $\begin{array}{l}\text { Chelating } \\
\text { agent }\end{array}$ & $\begin{array}{l}\text { Route of } \\
\text { administration }\end{array}$ & Dose & Animal model & Effect & Ref. \\
\hline $\begin{array}{l}\text { DED; BGD; } \\
\text { PBGD }\end{array}$ & i.p. & $\begin{array}{l}0.4,1 \text { or } 3 \mathrm{mmol} / \mathrm{kg} \\
\text { b.w., after Cd-treatment }\end{array}$ & $\begin{array}{l}\text { Rats, intoxicated with } 3 \\
\mathrm{mg} / \mathrm{kg} \text { Cd(II) s.c. }\end{array}$ & $\begin{array}{l}\text { Combinations of DED and BGD or DED and PBGD } \\
\text { prevented sterility caused by Cd and decrease Cd } \\
\text { in the testes. }\end{array}$ & {$[91,92]$} \\
\hline Mi-ADMS & i.p. & $\begin{array}{l}0,5 \mathrm{mmol} / \mathrm{kg} \text { b.w., after } \mathrm{Cd}- \\
\text { intoxication }\end{array}$ & $\begin{array}{l}\text { Rats, intoxicated with } 0,03 \\
\text { mmol/kg Cd(II) chloride, } \\
\text { i.p. }\end{array}$ & $\begin{array}{l}\text { The chelating agent, applied } 1 \mathrm{~h} \text { after } \mathrm{Cd} \text { - } \\
\text { administration reduces Cd-induced apoptosis and } \\
\text { DNA fragmentation. }\end{array}$ & {$[98,99]$} \\
\hline DSF; DED & i.p. & $\begin{array}{l}\text { DED - 0, 1; } 1 \mathrm{mmol} / \mathrm{kg} \text { b.w.; } \\
\text { DSF - 0,05; } 5 \mathrm{mmol} / \mathrm{kg} \text { b.w. } \\
\text { applied after Cd-intoxication }\end{array}$ & $\begin{array}{l}\text { Rats, injected (s.c.) with } 3 \\
\mathrm{mg} / \mathrm{kg} \mathrm{Cd}\end{array}$ & $\begin{array}{l}\text { DSF inhibits Cd-induced LPO; reduces testicular } \\
\text { damage caused by Cd and restores Fe } \\
\text { homeostasis. }\end{array}$ & [93] \\
\hline$(\mathrm{PhSe})_{2} ; \mathrm{DMSA}$ & $\begin{array}{l}\text { Information not } \\
\text { found }\end{array}$ & Information not found & $\begin{array}{l}\text { Mice, exposed to } 2.5 \\
\mathrm{mg} / \mathrm{kg} \text { b.w. Cd(II) chloride } \\
\text { or } 5 \mathrm{mg} / \mathrm{kg} \text { b.w. Cd(II) } \\
\text { chloride (i.p) }\end{array}$ & $\begin{array}{l}\text { Both compounds in combination or alone do not } \\
\text { improve the ascorbic acid and SOD activity in } \\
\text { mice, exposed to } 5 \mathrm{mg} / \mathrm{kg} \mathrm{Cd}(\mathrm{II}) \text { chloride. }\end{array}$ & [94] \\
\hline$(\mathrm{PhSe})_{2}$; DMPS & $\begin{array}{l}\text { Information not } \\
\text { found }\end{array}$ & Information not found & $\begin{array}{l}\text { Mice, exposed to } 2.5 \\
\text { mg/kg b.w. Cd(II) chloride } \\
\text { or } 5 \mathrm{mg} / \mathrm{kg} \text { b.w. Cd(II) } \\
\text { chloride (i.p) }\end{array}$ & $\begin{array}{l}\text { The chelating agents partially inhibit Cd-induced } \\
\text { toxicity caused by } 2.5 \mathrm{mg} / \mathrm{kg} \mathrm{Cd}(\mathrm{II}) \text { chloride. } \\
\text { Combined therapy decreases Cd concentration in } \\
\text { testes and recovers plasma AST, elevated by } 5 \\
\mathrm{mg} / \mathrm{kg} \text { Cd(II) chloride. }\end{array}$ & [95] \\
\hline$(\mathrm{PhSe})_{2}$ & s.c. & $\begin{array}{l}5 \mathrm{micromol} / \mathrm{kg} \text { b.w., in } 30 \mathrm{~min} \\
\text { after Cd five weekly, } 4 \text { weeks }\end{array}$ & $\begin{array}{l}\text { Mice, exposed to } \\
\text { subchronic intoxication } \\
\text { with Cd(II) chloride } \\
\text { (s.c. } 2.5 \mathrm{mg} / \mathrm{kg} \text {, five times } \\
\text { weekly, } 4 \text { weeks) }\end{array}$ & $\begin{array}{l}\text { The antioxidants, enhanced Cd-induced testicular } \\
\text { injury. }\end{array}$ & [96] \\
\hline Monensin & p.o. & $\begin{array}{l}14 \mathrm{mg} / \mathrm{kg} \text {, applied after } \mathrm{Cd}- \\
\text { intoxication }\end{array}$ & $\begin{array}{l}\text { Mice, exposed to subacute } \\
\text { intoxication with Cd(II) } \\
\text { acetate for } 2 \text { weeks ( } 10 \\
\mathrm{mg} / \mathrm{kg} \text { b.w.) }\end{array}$ & $\begin{array}{l}\text { Monensin reduces Cd concentration in the testes } \\
\text { by } 50 \% \text { compared to the normal control and } \\
\text { recovers the histology of the testes to a great } \\
\text { extent. }\end{array}$ & [97] \\
\hline
\end{tabular}

Disulfiram (DSF); Diphenyl diselenide (PhSe)2. 


\begin{tabular}{|c|c|c|c|c|c|}
\hline Compound & $\begin{array}{l}\text { Route of } \\
\text { administration }\end{array}$ & Dose & Animal model & Effect & Ref. \\
\hline$\overline{\text { DMPS }}$ & i.v. & n.a. & $\begin{array}{l}\text { Rabbits, intoxicated with } \\
\text { Cd(II) chloride } 50 \mathrm{mg} / \mathrm{kg} \\
\text { b.w./week for } 10 \text { weeks }\end{array}$ & $\begin{array}{l}\text { The chelating agent decreases Ca and Mg } \\
\text { concentration in the cardiac muscle. }\end{array}$ & [105] \\
\hline $\begin{array}{l}\text { Caffeic acid } \\
\text { phenyl ester }\end{array}$ & i.p. & $\begin{array}{l}10 \mu \mathrm{mol} / \mathrm{kg} \text { b.w., for } 15 \text { days } \\
\text { along with Cd }\end{array}$ & $\begin{array}{l}\text { Rats, intoxicated with } \\
\mathrm{Cd}(\mathrm{II}) \text { chloride } 1 \\
\mathrm{mg} / \mathrm{kg} / \text { day for } 15 \text { days } \\
\text { (i.p.) }\end{array}$ & $\begin{array}{l}\text { The antioxidant decreases MDA level in the } \\
\text { cardiac muscle in the Cd-treated rats; increases } \\
\text { NO in the serum and inhibits Cd-induced } \\
\text { myocardial hypertrophy. }\end{array}$ & {$[100]$} \\
\hline $\begin{array}{l}\text { Vitamin E and } \\
\text { coenzyme Q } \\
\text { (10) }\end{array}$ & i.m. & $\begin{array}{l}\text { Vitamin E - } 20 \mathrm{IU} / \mathrm{kg} / \mathrm{b} . \mathrm{w} \text {. } \\
\text { Q10 - } 20 \mathrm{mg} / \mathrm{kg} \text { b.w. } \\
\text { concurrent with Cd }\end{array}$ & $\begin{array}{l}\text { Rats, exposed to } 0.4 \\
\mathrm{mg} / \mathrm{kg} \text { Cd (i.p.) }\end{array}$ & $\begin{array}{l}\text { The combination of both oxidants diminishes the } \\
\text { toxic effects induced by Cd. }\end{array}$ & {$[101]$} \\
\hline $\begin{array}{l}\text { Taurine } \\
\text { Vitamin C }\end{array}$ & p.o. & $\begin{array}{l}100 \mathrm{mg} / \mathrm{kg} \text { b.w. for } 5 \text { days, } \\
\text { prior to Cd-intoxication }\end{array}$ & $\begin{array}{l}\text { Mice, received Cd(II) } \\
\text { chloride for } 6 \text { days ( } 4 \\
\text { mg/kg b.w.) }\end{array}$ & $\begin{array}{l}\text { Both antioxidants decrease Cd concentration in } \\
\text { the cardiac muscle, improve antioxidant defence } \\
\text { system and preserve the normal histoarchitecture } \\
\text { of the heart. }\end{array}$ & [103] \\
\hline $\begin{array}{l}\text { Diethyl } \\
\text { carbamate }\end{array}$ & $\begin{array}{l}\text { Data not } \\
\text { available }\end{array}$ & Data not available & $\begin{array}{l}\text { Rats, exposed to } 20 \mathrm{mg} / \mathrm{kg} \\
\text { b.w. Cd or } 40 \mathrm{mg} / \mathrm{kg} \text { b.w. } \\
\text { Cd/ daily for } 60 \text { days }\end{array}$ & $\begin{array}{l}\text { The chelating agent reduces } \mathrm{Cd} \text { concentration by } \\
36 \% \text { compared to the control and recovers } \mathrm{Fe} \\
\text { homeostasis. }\end{array}$ & [69] \\
\hline DMSA & Intragastrically & $\begin{array}{l}25 \mathrm{mg} / \mathrm{kg} \\
50 \mathrm{mg} / \mathrm{kg} \text { for } 5 \text { days after Cd- } \\
\text { intoxication }\end{array}$ & $\begin{array}{l}\text { Mice, treated with } 100 \\
\mathrm{mg} / \mathrm{L} \text { for } 8 \text { weeks }\end{array}$ & $\begin{array}{l}\text { DMSA reduces the concentration of Cd in blood, } \\
\text { heart, liver and kidneys, improves blood pressure } \\
\text { and antioxidant defence system in the heart. }\end{array}$ & [104] \\
\hline $\begin{array}{l}\alpha \text {-Lipoic acid } \\
\text { (ALA) } \\
\text { melathonin }\end{array}$ & $\begin{array}{l}\text { Information not } \\
\text { found }\end{array}$ & $\begin{array}{l}\text { ALA - } 25 \mathrm{mg} / \mathrm{kg} \text { b.w. /day; } \\
\text { Melathonin - } 10 \mathrm{mg} / \mathrm{kg} \\
\text { b.w./day, } \\
\text { applied together with Cd(II) }\end{array}$ & $\begin{array}{l}\text { Rats, subjected to } \\
\text { subchronic Cd intoxication } \\
5 \mathrm{mg} / \mathrm{kg} \text { b.w. / day for } 15 \\
\text { days }\end{array}$ & $\begin{array}{l}\text { The combination of both agents inhibits Cd- } \\
\text { induced cardiac impairment. }\end{array}$ & [102] \\
\hline Monensin & p.o. & $\begin{array}{l}14 \mathrm{mg} / \mathrm{kg} \text { after } \mathrm{Cd} \text { intoxication } \\
\text { for } 2 \text { weeks }\end{array}$ & $\begin{array}{l}\text { Mice, exposed to } 10 \\
\mathrm{mg} / \mathrm{kg} \text { daily Cd(II) acetate } \\
\text { for } 2 \text { weeks }\end{array}$ & $\begin{array}{l}\text { Monensin reduces Cd concentration in the heart } \\
\text { by } 90 \% \text { compared to the control and recovers the } \\
\text { morphology of the heart. }\end{array}$ & [47] \\
\hline
\end{tabular}

Our results have demonstrated that monensin (applied as tetraethylammonium salt) reduces $\mathrm{Cd}$ concentration in the testes of Cd-treated mice by $50 \%$ compared to the control. The administration of the chelating agent to the Cd-intoxicated mice restored the histology of the testes to normal to a great exent [97].

\section{Antioxidants and chelating agents, tested to inhibit Cd- induced cardiac impairment}

Cd is a vascular toxicant that induces hypertension and myocardial hypertrophy. The generation of ROS either by affecting Fe homeostasis or NO level in the endothelial cells has been considered as a primary mechanism for Cd-induced cardiac toxicity.

$\mathrm{Cd}$ induces expression of stress genes which in turn alters the activity of the antioxidant enzymes [100]. The antioxidants and chelating agents, screened on animal models to prevent $\mathrm{Cd}-$ induced cardiac toxicity, are summarized in Table 10.

The combination of coenzyme $Q(10)$ and Vitamin $E$ has been demonstrated to reverse Cd-induced alterations in the antioxidant defense system of heart of rats, exposed to acute Cd-intoxication [101].

Caffeic acid phenyl ester (CAPE) administrated concurrent with Cd prevents the morphological alterations, induced by $\mathrm{Cd}$ in the heart of Cd-treated rats by decreasing lipid peroxidation and improving NO homeostasis [100].

The combination of $\alpha$-lipoic acid and melatonin applied along with the $\mathrm{Cd}$ treatment also inhibits Cd-induced cardiac impairment in rats, subjected to subchronic Cd-intoxication [102].

Vitamin C and taurine, applied before Cd-intoxication, decrease $\mathrm{Cd}$ accumulation in the heart of mice, exposed to subacute Cd-intoxication. Vitamin C is more effective than taurine in preventing the activity of the antioxidant enzymes and the level of GSH in the cardiac muscle. The cardioprotective effect of both antioxidants is substantiated by the reduction of Cd-induced pathological changes in the cardiac tissue [103].

Among the chelating agents, DMSA and monensin seem to be the most effective in decreasing $\mathrm{Cd}$ concentration in the heart of animals, intoxicated with $\mathrm{Cd}[47,104]$.
2,3-Dimercapto-1-propanesulphonate (DMPS) also decreases $\mathrm{Cd}$ concentration in the cardiac muscle of Cd-treated animals. However, precautions should be taken in its application in patients with cardiotoxicity because of its affect on the $\mathrm{Ca}$ and $\mathrm{Mg}$ concentration in the heart [105].

\section{Conclusion}

There are many published reviews on chelating agents and antioxidants tested for the treatment of intoxications with toxic metal ions. To the best of our knowledge however this is the first review that summarizes the literature information published in the last 20 years for the antioxidants and chelating agents, tested on animal models for the treatment of $\mathrm{Cd}$ induced organ toxicity. Detailed information regarding the $\mathrm{Cd}-$ induced pathological conditions (hepatotoxicity, renal dysfunction, reproductive disorder and cardiac impairment) is also presented. The data discussed in the review demonstrate the necessity of development of effective scheme for therapy of humans, exposed to Cd-intoxication. Based on the data, presented in this paper, it could be concluded that the simultaneous application of antioxidants and chelating agents could be a good approach for the treatment of Cd-induced organ toxicity. In order to identify the best antioxidant and chelating agent for the treatment of Cd-induced pathological conditions, detailed studies for their effects on different organs in animals, exposed to Cd-intoxications are needed.

\section{References}

[1]. IARC, International Agency for Research on Cancer, Beryllium, cadmium, mercury, and exposures in the glass manufacturing industry. In International Agency for Research on Cancer Monographs on the Evaluation of Carcinogenic Risk to Humans; IARC Scientific publications; Lyon, France, 1993; Volume 58, 119-237.

[2]. WHO, Cadmium: Air Quality Guidelines, 2nd ed. World Health Organization, Regional office for Europe, Copenhagen, Denmark, Chapter 6.3., 2000.

[3]. Patrick, L. Altern. Med. Rev. 2003, 8(2), 106-128.

[4]. Djukovic-Cosic, D. C.; Jovanovic, M.; Bulat, Z. P.; Ninkovic, M. Malicevic, Z.; Matovic, V.J. Trace Elem. Med. Biol. 2008, 22, 67-72.

[5]. Thijssen, S.; Lambrichts, I.; Maringwa, J.; Kerkhove, E. V. Toxicol. 2007, 238, 200-210. 
[6]. Thijssen, S.; Maringwa, J.; Faes, Ch.; Lambrichts, I.; Kerkhove, E. V. Toxicol. 2007, 229, 145-156.

[7]. Oliviera, H.; Spano, M.; Santos, C.; Pereira, M. Reproductive Toxicol. 2009, 28, 550-555.

[8]. Monsefi, M.; Alaee, S.; Moradshahi, A.; Rohani, L. Environ. Toxicol. 2010, 25, 94-102

[9]. Prozialeck, W. C.; Edwards, J. R.; Woods, J. M. Life Sci. 2006, 79, 14931506.

[10]. Prozialeck, W. C.; Edwards, J. R.; Nebert, D. W.; Woods, J. M.; Barchowsky, A.; Atchison. W. D. Toxicol. Sci. 2008, 102, 207-218.

[11]. Satarug, S.; Nishijo, M.; Ujjin, P.; Vanavanitkun, Y.; Moore, M. R. Toxicol. Lett. 2005, 157, 57-68.

[12]. Smetana, R.; Glogar, D.; Weidinger, F.; Meisinger, V. Wien. Med. Wochensch. 1987, 137, 553-557.

[13]. Teller-Plaza, M.; Navas-Acien, A.; Crainiceanu, C. M.; Sharrett, A. R.; Guallar, E. Am. J. Epidemiol. 2010, 172, 671-681.

[14]. Peters, J. L.; Perlstein, T. S.; Perry, M. L.; McNeely, E.; Weuve, J. Environ. Res. 2010, 110, 199-206.

[15]. Flora, S. J.; Mittal, M.; Mehta, M. A. Indian J. Med. Res. 2008, 128, 501523.

[16]. Blanusa, M.; Varnai, V. M.; Piasek, M.; Kostial, K. Current Med. Chem. 2005, 12, 2771-2794.

[17]. Sinicropi, M. S.; Amantea, D.; Caruso, A.; Sturnino, C. Arch. Toxicol. 2010, 84, 501-520.

[18]. Andjuar, P.; Bensefa-Colas, L.; Descatha, A. Rev. Med. Interne. 2010, 31, 107-115.

[19]. Jurczuk, M.; Galazyn-Sidorczuk, M.; Brzorska, M. M.; MoniuszkoJakoniuk, J. Polish J. Environ. Studies 1997, 6, 74-76.

[20]. Snaikh, Z. Z.; Vu, T. T.; Zaman, K. Toxicol. Appl. Pharmacol. 1999, 154, 256-263.

[21]. Ercal, N.; Guerer-Orhan, H.; Aykin-Burns, N. Current Topics in Med. Chem. 2001, 1, 529-539.

[22]. Sinha, M.; Manna, P.; Sil, P. C. J. Trace Elem. Med. Biol. 2009, 23, 300313.

[23]. Fouad, A. A.; Qureshi, H. A.; Yacoubi, M. T.; Al-Melhim, W. N. Food Chem. Toxicol. 2009, 47, 863-870.

[24]. Pari, L.; Shagirtha, K. Exp. Toxicol. Pathol. 2012, 64, 513-520.

[25]. Bludovska, M.; Kotyzova, D.; Koutensky, J.; Eybl, V. Gen Physiol Biophys. 1999, 18, 28-32

[26]. Eybl, V.; Kotyzova, D.; Bludovska, M. Toxicol Lett. 2004, 151, 79-85.

[27]. Eybl, V.; Kotyzova. D.; Leseticky, L.; Bludovska, M.; Koutensky, J. J Appl. Toxicol. 2006, 26, 207-212.

[28]. Eybl, V.; Kotyzova, D.; Koutensky, J. Toxicol. 2006, 225(2-3), 150-156.

[29]. Murugavel, P.; Pari, L. Hum. Exp. Toxicol. 2007, 26, 527-534.

[30]. Pari, L.; Murugavel, P.; Sitasawad, S. L.; Kumar, K. S. Life Sci. 2007, 80, 650-658.

[31]. Gong, P.; Chen, F. X.; Ma, G. F.; Feng, Y.; Zhao, Q.; Wang, R. Toxicol. 2008, 251, 35-44

[32]. Nemmiche, S.; Chabane-Sari, D.; Guiraud, P. Chem. Biol. Interact. 2007, 170, 221-230.

[33]. Olalekan, L. A.; Lawal, A. F.; Ologundudu, A.; Adeniran, O. Y.; Omonkhua, A.; Obi, F. Toxicol. Sci. 2011, 36, 549-557.

[34]. Shukla, R.; Kumar, M. Food Chem. Toxicol. 2009, 47, 769-773.

[35]. Chlebda, E.; Magdalan, J.; Merwid-Lad, A.; Trocha, M.; Kopacz. M.; Kuźniar, A.; Nowak, D.; Szelag, A. Exp. Toxicol. Pathol. 2010, 62, 105158.

[36]. Santos, F. W.; Zeni, G. , Rocha, J. B.; Weis, S. N. , Fachinetto, J. M.; Favero, A. M.; Nogueira, C. W. Chem. Biol. Interact. 2005, 151, 159-65.

[37]. Borges, L. P.; Brandao, R.; Godoi, B.; Nogueira, C. W.; Zeni, G. Chem. Biol. Interact. 2008, 171, 15-25.

[38]. Chwelatiuk, E.; Wlostowski, T.; Krasowska, A.; Bonda, E. J. Trace Elem. Med. Biol. 2006, 19, 259-265.

[39]. Sk, U. H.; Sharma, A. K.; Ghosh, S.; Bhattacharya, S. Eur. J. Med. Chem. 2010, 45, 3265-3273.

[40]. Renugadevi, J.; Prabu, S. M. Exp Toxicol Pathol. 2010, 62, 171-181.

[41]. Prabu, S. M.; Shagirtha, K.; Renugadevi, J. J. Nutr. Sci. Vitaminol (Tokyo) 2011, 57, 177-185.

[42]. Casalino, E.; Calzaretti, G.; Sblano, C.; Landriscina, V.; Felice, Tecce M.; Landriscina, C. Comp. Biochem. Physiol. C. Toxicol. Pharmacol. 2002, 133, 625-632.

[43]. Asagba, S. O.; Adaikpoh, M. A.; Kadiri, H.; Obi, F. O. Biol. Trace Elem. Res. 2007, 115, 47-57.

[44]. Eybl, V.; Kotyzova, D.; Koutensky, J.; Jones, M. M.; Singh, P. K. Analyst 1995, 120, 855-857.

[45]. Srivastava, R. C.; Gupta, S.; Ahmad, N.; Hasan, S. K.; Farookh, A.; Husain, M. M. J. Toxicol. Environ. Health 1996, 47, 173-182.

[46]. Singh, P. K.; Jones, M. M.; Rostial, K.; Blanusa, M.; Piasek, M.; RestekSamarzija, N. Chem. Res. Toxicol. 1996, 9, 965-969.

[47]. Ivanova, J.; Gluhcheva, Y.; Kamenova, K.; Arpadjan, S.; Mitewa, M. J. Trace Elem. Med. Biol. 2012, 26, 279-284.

[48]. Ivanova, J.; Gluhcheva, Y.; Kamenova, K.; Arpadjan, S.; Mitewa, M. Biotechnol. Biotechnol. Eq. 2013, in press.

[49]. Eybl, V.; Kotyzova, D.; Koutensky, J.; Míckova, V.; Jones, M. M.; Singh, P. K. Analyst 1998, 123, 25-26.

[50]. Suru, S. M. Biometals. 2008, 21, 623-633.

[51]. Cavusoglu, K.; Yapar, K.; Yalcin, E. J. Med. Food. 2009, 12, 1286-1292.
[52]. Manna, P.; Sinha, M.; Sil, P. C. Amino Acids 2009, 36, 417-428.

[53]. Li, R.; Yuan, C.; Dong, C.; Shuang, S.; Choi, M. M. Naunyn Schmiedebergs Arch. Pharmacol. 2011, 383, 437-445.

[54]. Gong, P.; Chen, F.; Liu, X.; Gong, X.; Wang. J.; Ma, Y. J. Toxicol. Sci. 2012, 37, 415-425

[55]. Kaplan, M.; Atakan, I. H.; Aydogdu, N.; Aktoz, T.; Ozpuyan, F.; Seren, G.; Tokuc, B.; Inci, O. Pediatr. Nephrol. 2008, 23, 233-241.

[56]. Wang, L.; Chen, D.; Cao, J.; Liu, Z. Hum. Exp. Toxicol. 2009, 28, 221-229.

[57]. Renugadevi, J.; Prabu, S. M. Toxicol. 2009, 256, 128-134.

[58]. Morales, A. I.; Vicente-Sanchez, C.; Jerkic, M.; Santiago. J. M.; SanchezGonzalez, P. D.; Perez-Barriocanal, F.; López-Novoa, J. M. Toxicol. Appl Pharmacol. 2006, 210, 128-135.

[59]. Renugadevi, J.; Prabu, S. M. Exp. Toxicol. Pathol. 2010, 62, 471-481.

[60]. Prabu, S. M.; Shagirtha, K.; Renugadevi, J. Rev. Med. Pharmacol. Sci. 2010, 14, 903-914.

[61]. Bharavi, K.; Reddy, A. G.; Rao, G. S.; Kumar, P. R.; Kumar, D. S. Prasadini, P. P. Indian J. Pharmacol. 2011, 43, 45-49.

[62]. Shaikh, Z. A.; Vu, T. T.; Zaman, K. Toxicol. Appl. Pharmacol. 1999, 154, 256-263.

[63]. Fouad, A. A.; Jresat, I. Life Sci. 2011, 89, 29-35.

[64]. Jones, M. M.; Singh, P. K.; Basinger, M. A.; Gale, G. R.; Smith, A. B. Pharmacol. Toxicol. 1994, 74, 76-83.

[65]. Jones, M. M.; Xu, C.; Singh, P. K.; Walker, E. M. Jr. J. Toxicol. Environ. Health. 1996, 48, 71-80.

[66]. Tandon, S. K.; Prasad, S.; Singh, S. Biomed. Environ. Sci. 2000, 13, 205 212.

[67]. Fatemi, S. J.; Saljooghi, A. S.; Balooch, F. D.; Iranmanesh, M.; Golbafan, M. R. Toxicol. Ind. Health. 2012, 28, 35-41.

[68]. Jones, M. M.; Singh, P. K.; Basinger, M. A.; Gale, G. R.; Smith, A. B Harris, W. R. Chem. Res. Toxicol. 1994, 7, 367-373.

[69]. Fatemi, S. J.; Tubafard, S.; Nadi, B. Med. Chem Res. 2009, 18, 179-186.

[70]. Shagirtha, K.; Pari, L. Ecotoxicol. Environ. Saf. 2011, 74, 2105-2111.

[71]. Sen Gupta, R.; Kim, J.; Gomes, C.; Oh, S.; Park, J.; Im, W. B.; Seong, J. Y.; Ahn, R. S.; Kwon, H. B.; Soh, J. Mol Cell Endocrinol. 2004, 221, 57-66.

[72]. Sen Gupta, R.; Sen Gupta, E.; Dhakal, B. K.; Thakur, A. R.; Ahnn, J. Mol. Cells 2004, 17, 132-139.

[73]. Acharya, U. R.; Mishra, M.; Patro, J.; Panda, M. K. Reprod. Toxicol. 2008, 25, 84-88.

[74]. Fouad, A. A.; Qureshi, H. A.; Al-Sultan, A. I.; Yacoubi, M. T.; Ali, A. A Toxicol. 2009, 257, 153-160.

[75]. Brandao, R.; Santos, F. W.; Oliveira, R.; Roman, S. S.; Nogueira, C. W. J. Trace Elem. Med. Biol. 2009, 23, 324-333.

[76]. Ognjanovic, B. I.; Markovic, S. D.; Ethordevic, N. Z.; Trbojevic, I. S.; Stajn, A. S.; Saicic, Z. S. Reprod. Toxicol. 2010, 29, 191-197.

[77]. Ji, Y. L.; Wang, H.; Meng, C.; Zhao, X. F.; Zhang, C.; Zhang, Y.; Zhao, M.; Chen, Y. H.; Meng, X. H.; Xu, D. X. J. Pineal Res. 2012, 52, 71-79.

[78]. El-Missiry, M. A.; Shalaby, F. J. Biochem. Mol. Toxicol. 2000, 14, 238243.

[79]. El-Demerdash, F. M.; Yousef, M. I.; Kedwany, F. S.; Baghdadi, H. H. Food Chem. Toxicol. 2004, 42, 1563-1571.

[80]. Yang, H. S.; Han, D. K.; Kim, J. R.; Sim, J. C. J. Korean Med. Sci. 2006 21(3), 445-451.

[81]. El-Maraghy, S. A.; Nassar, N. N. J. Biochem. Mol. Toxicol. 2011, 25, 1525.

[82]. Rajendar, B.; Bharavi, K.; Rao, G. S.; Kishore, P. V.; Kumar, P. R.; Kumar C. S.; Kumar, D. S. Indian J. Physiol. Pharmacol. 2011, 55, 213-220.

[83]. Rajendar, B.; Bharavi, K.; Rao, G. S.; Kishore, P. V.; Kumar, P. R.; Kumar, C. S.; Patel T. P. Indian J. Pharmacol. 2011, 43, 568-573.

[84]. Ponnusamy, M.; Pari, L. Toxicol. Ind. Health 2011, 27, 407-416.

[85]. Ardais, A. P.; Santos, F. W.; Nogueira, C. W. J. Appl. Toxicol. 2008, 28, 322-328.

[86]. Sadik, N. A. J. Biochem. Mol. Toxicol. 2008, 22, 345-353.

[87]. Ola-Mudathir, K. F.; Suru, S. M.; Fafunso, M. A.; Obioha, U. E.; Faremi, T. Y. Food Chem. Toxicol. 2008, 46, 3604-3611.

[88]. Leite, R. P.; Wada, R. S.; Monteiro, J. C.; Predes, F. S.; Dolder, H. Biol. Trace Elem. Res. 2011, 141, 262-274.

[89]. Bu, T.; Mi, Y.; Zeng, W.; Zhang, C. Anat. Rec. (Hoboken). 2011, 294, 520526.

[90]. Onwuka, F. C.; Erhabor, O.; Eteng, M. U.; Umoh, I. B. J. Med. Food 2011 $14,817-821$

[91]. Kojima, S.; Sugimura, Y.; Hirukawa, H.; Kiyozumi, M.; Shimada, H.; Funakoshi, T. Toxicol. Appl. Pharmacol. 1992, 116, 24-29.

[92]. Kojima, S.; Sugimura, Y.; Ono, H.; Shimada, H.; Funakoshi, T. Biol Pharm Bull. 1993, 16, 244-247.

[93]. Ono, H.; Funakoshi, T.; Shimada, H.; Kojima, S. J. Toxicol. Environ. Health 1997, 50, 389-399.

[94]. Santos, F. W.; Oro, T.; Zeni, G.; Rocha, J. B.; do Nascimento, P. C.; Nogueira, C. W. Toxicol. Lett. 2004, 152, 255-263.

[95]. Santos, F. W.; Graça, D. L.; Zeni, G.; Rocha, J. B.; Weis, S. N.; Favero, A. M.; Nogueira, C. W. Reprod Toxicol. 2006, 22, 546-550.

[96]. Santos, F. W.; Zeni, G.; Rocha, J. B. , do Nascimento, P. C.; Marques, M. S.; Nogueira, C. W. Food Chem. Toxicol. 2005, 43, 1723-1730.

[97]. Pavlova, E.; Ivanova J.; Dimova, D.; Gluhcheva, Y.; Atanasova, N. Eur Chem. Bull. 2012, 1, 463-465.

[98]. Xu, C.; Holscher, M. A.; Jones, M. M.; Singh, P. K. J. Toxicol. Environ. Health. 1995, 45, 261-277. 
[99]. Xu, C.; Johnson, J. E.; Singh, P. K.; Jones, M. M.; Yan, H.; , Carter, C. E. Toxicol. 1996, 107, 1-8.

[100]. Mollaoglu, H.; Gokcimen, A.; Ozguner, F.; Oktem, F.; Koyu, A.; Kocak, A.; Demirin, H.; Gokalp, O.; Cicek, E. Toxicol. 2006, 227, 15-20.

[101]. Ognjanovic, B. I.; Markovic, S. D.; Pavlovic, S. Z.; Zikic, R. V.; Stajn, A. S.; Saicic, Z. S. Environ. Toxicol. Pharmacol. 2006, 22, 219-224.

[102]. Mukherjee, R.; Banerjee, S.; Joshi, N.; Singh, P. K.; Baxi, D, Ramachandran, A. V. Cardiovasc. Toxicol. 2011, 11, 78-88.

[103]. Manna, P.; Sinha, M.; Sil, P. C. Chem Biol Interact. 2008, 174, 88-97.

[104]. Sompamit, K.; Kukongviriyapan, U.; Donpunha, W.; Nakmareong, S.; Kukongviriyapan, V. Toxicol. Lett. 2010, 198, 77-82.

[105]. Hrdina, R.; Gersl, V.; Vavrova, J.; Holeckova, M.; Palicka, V.; Voglova, J.; Mazurova, Y.; Bajgar, J. Hum. Exp. Toxicol. 1998, 17, 221-224. 